\title{
Relacje władz i społeczeństwa Ślq̨ska Opolskiego z Polakami na Zaolziu (wybrane elementy)
}

\section{LEOKADIA DROŻDŻ}

Państwowy Instytut Naukowy - Instytut Śląski w Opolu

\section{ROCZNIK}

\section{ZIEM}

\section{ZACHODNICH}

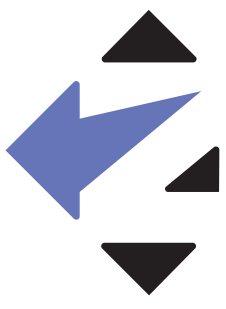


Przez długie lata po II wojnie światowej kontakty władz i społeczeństwa Śląska Opolskiego z Polakami na Zaolziu były dość sporadyczne. Główną przyczyną takiego stanu rzeczy były spory terytorialne, które dominowały w stosunkach politycznych Polski i Czechosłowacji w latach 1945-1948. Strona polska dążyła do uzyskania części Śląska Cieszyńskiego zamieszkanego w większości przez polską ludność. Natomiast strona czechosłowacka usiłowała doprowadzić do zmiany przynależności powiatów kłodzkiego, głubczyckiego i raciborskiego. Temat ten był obiektem zainteresowań historyków, polskich i czeskich ${ }^{1}$. Autorem wielu artykułów na ten temat jest Piotr Pałys². Zagadnieniami tymi zajmował się również znawca dziejów stosunków polsko-czechosłowackich Marek Kazimierz Kamiński, który opisał kontakty między obu tymi państwami w latach 1945-1960. Bezpośrednio po II wojnie światowej polsko-czechosłowackie stosunki polityczne miały niezwykle ożywiony charakter, gdyż każde państwo chciało zrealizować swoje „pretensje” terytorialne wobec obszaru sąsiada ${ }^{3}$. Kolejne lata (1948-1955) to faza stagnacji. Zgodnie z praktyką przyjętą przez Józefa Stalina kontakty te ograniczały się do kwestii drugorzędnych. Rok 1956 ujawnił natomiast przepaść między kierownictwem Polskiej Zjednoczonej Partii Robotniczej (PZPR) a władzami Komunistycznej Partii Czechosłowacji (KPCz), wprawdzie 18 listopada 1956 r., po wizycie Wiesława Gomułki w ZSRR, przywódcy KPCz wycofali wojska czechosłowackie znad granicy, ale nie spieszyli się z nawiązaniem poprawnych stosunków z nowym kierownictwem PZPR ${ }^{4}$.

1 Szerzej na temat pisali m.in.: K. Nowak, Mniejszość Polska w Czechosłowacji 1945-1989. Między nacjonalizmem a idea nacjonalizmu, Cieszyn-Katowice 2010, s. 45-71; idem, Nieznany plan przejęcia władzy na Zaolziu przez Polaków w 1944 roku, „Pamiętnik Cieszyński”, (1994), t. 4, s. 148-151; J. Friedl, Češi a Poláci na Těšínsku, Praha-Brno 2012; G. Pańko, Polska i Polacy w Czeskiej opinii publicznej w okresie międzywojennym, „Acta Universitatis Wratislaviensis” nr 1829, Wrocław 1996, s. 13-27; M.W. Wanatowicz, Historia społeczno-polityczna Górnego Ślqska i Ślqska Cieszyńskiego w latach 1918-1945, Katowice 1994, s.14-22; B.S. Kunda, Polska mniejszość narodowa w Czechosłowacji w latach 1945-1950, [w:] Z polsko-czechosłowackiego sqsiedztwa. Studia i szkice, red. E. Kopeć, Katowice 1985, s. 75-95; Nástin dějin Těšínska oprac. M. Borák, D. Gawrecki, Ostrava 1992, s. 81-86; D. Gawrecki [et al.], Dějiny Českého Slezska 17402000, t. 1, Opava 2003, s. 298-303; G. Kasztura, Działania Armii Czerwonej na Ślqsku Cieszyńskim wiosna 1945 roku a kwestia powojennej przynależności państwowej Zaolzia, „Pamiętnik Cieszyński”, (2016), t. 21, s. $107-125$.

2 P. Pałys, Konflikt polsko-czechosłowacki z lat 1945-1946 w aktach Komitetów Powiatowych PPR $w$ Raciborzu i Głubczycach, „Śląsk Opolski”, (1991), nr 3, s. 19-21; idem, Uchodźcy z Zaolzia na Opolszczyźnie w latach 1945-1948, „Pamiętnik Cieszyński”, (1992), t. 4, s. 110-114; idem, Repatrianci z Czechosłowacji w aktach Powiatowych Oddziałów Państwowego Urzędu Repatriacyjnego na Śląsku Opolskim, „Śląski Kwartalnik Historyczny Sobótka", R. XLIX (1994), nr 1-2, s. 129-136; idem, Sytuacja na Zaolziu u schyłku 1945 roku w ocenie Powiatowego Urzędu Informacji i Propagandy w Raciborzu, „Pamiętnik Cieszyński”, (1994), t. 4, s. 152-154; idem, Polsko-czechosłowacki spór o przynależność ziemi kłodzkiej w latach 19451947, „Kwartalnik Opolski”, R. XLI (1995), nr 3-4, s. 31-49; idem, Ze źródeł do polsko-czechosłowackiego konfliktu granicznego w latach 1945-1947, „Pamiętnik Cieszyński”, (1996), t. 11, s. 73-78; idem, W kwestii czeskiej akcji zbrojnej w Kłodzkiem, Głubczyckiem i Raciborskiem oraz polskiej na Ślasku Cieszyńskim w 1945 r., „Pamiętnik Cieszyński”, (1998), t. 13, s. 44-49; idem, Administracja polska wobec ludności czeskiej na pograniczu polsko-czechosłowackim w latach 1945-1947, „Śląski Kwartalnik Historyczny Sobótka”, R. LV (2000), nr 2, s. 211-241; idem, Jak kształtowała się granica, „Fabryka Silesia - Kwartalnik”, nr $1(6 / 2014)$, s. 13-17.

3 M.K. Kamiński, Polsko-czechosłowackie stosunki polityczne 1945-1948, Warszawa 1990, s. 372.

4 M.K. Kamiński, Kształtowanie się stosunków polsko-czechosłowackich w latach 1948-1960, Warszawa 2012, s. 165 
Spór terytorialny położył się cieniem na relacje między obydwoma państwami, przeszły one długą drogę do normalizacji stosunków polsko-czechosłowackich po konflikcie o przynależność państwową Zaolzia. Dopiero od lat 60 . XX w. można zauważyć, że strona czechosłowacka stopniowo wycofywała się z obostrzeń, które ograniczały również kulturalne kontakty mniejszości polskiej z krajem macierzystym. Przywódcy obu państw zaczęli od składania sobie gratulacji i życzeń z okazji różnych państwowych rocznic. Także na Śląsku Opolskim nawiązano kontakty między Komitetem Wojewódzkim PZPR w Opolu, wojewódzkimi komitetami Frontu Jedności Narodu (FJN) i ich odpowiednikami w Czechosłowacji, a spotkania początkowo odbywały się głównie z okazji państwowych uroczystości rocznicowych lub jubileuszy polskich organizacji. Można tu wymienić: 15. rocznicę podpisania polsko-czechosłowackiego układu o przyjaźni5 ${ }^{5}$, 20-lecie Polskiego Związku Kulturalno-Oświatowego (PZKO) ${ }^{6}$ w Czechosłowacji w 1967 r., kiedy to Wojewódzki Komitet FJN w Opolu nadał tej organizacji Medal Tysiąclecia Państwa Polskiego za pracę społeczną w zakresie szerzenia kultury polskiej w Czechosłowackiej Republice Socjalistycznej (CSRS) oraz umocnienie przyjaźni polsko-czechosłowackiej. Delegacja z CSRS była zapraszana na liczne uroczystości, m.in. obchodów 30-lecia wyzwolenia ziemi opolskiej ${ }^{8}$.

W kolejnych latach do KW PZPR w Opolu wystosowywane były pisma, w których podkreślano potrzebę wspólnego omówienia form współpracy województwa opolskiego z przygranicznymi województwami czechosłowackimi. Powstały plany kontaktów i wymiany między KW PZPR w Opolu a KW KPCz w zakresie współpracy przemysłowej i kulturalno-oświatowej. W początkowej fazie była to przede wszystkim wymiana delegacji składających się z pracowników administracji szkolnej, ośrodków metodycznych, pracowników naukowych, nauczycieli oraz działaczy Związku Nauczycielstwa Polskiego. Natomiast w dziedzinie kultury postawiono na nawiązanie współpracy między działaczami Związku Literatów Polskich,

5 Archiwum Państwowe w Opolu (APO), Sprawozdania z [wizyt] delegacji [Polskiej Zjednoczonej Partii Robotniczej] za granicą, sygn. 827, Notatka dotycząca przebiegu uroczystego wieczoru przyjaźni, s. $15-16$.

6 Polski Związek Kulturalno-Oświatowy - organizacja społeczna, powołana w 1947 r., reprezentująca mniejszość polską w państwie czeskim, jej celem jest promocja i patronat nad kulturalną i edukacyjną aktywnością polskiej mniejszości; największą i najbardziej znaną imprezą pod patronatem PZKO jest coroczne Gorolskie Świeto w Jabłonkowie. PZKO współpracuje z polskimi szkołami na Zaolziu i ze Scena Polską w Teatrze Cieszyńskim w Czeskim Cieszynie. Zob. PZKO, red. P. Przeczek [et al.], Ostrava 1987 Leksykon PZKO, red. M. Radłowska-Obrusník, O. Toboły, Czeski Cieszyn 1997, s. 185; PZKO w roku 2007. Aneks do Leksykonu, red. F. Bałon, Czeski Cieszyn 2007; S. Zahradnik, M. Ryczkowski, Korzenie Zaolzia, Warszawa-Praga-Trzyniec 1992, s. 128-131.

7 Archiwum Związkowe Polskiego Związku Kulturalno-Oświatowego w Czeskim Cieszynie (AZ PZKO), Opole - Medal 1000-lecia Państwa Polskiego, sygn. 1538-531, Pismo w sprawie nadania PZKO Medalu Tysiąclecia Państwa Polskiego z dnia 30 VI 1967 r.

8 Zob. APO, Materiały dotyczące współpracy, wymiany i kontaktów zagranicznych Komitetu Wojewódzkiego 1974-1975, sygn. 830, Informacja dotycząca pobytu w woj. opolskim delegacji zagranicznych z Biełgorodu (ZSRR), Poczdamu (NRD), Bańskiej Bystrzycy (CSRS) w związku z obchodami XXX-lecia Wyzwolenia Ziemi Opolskiej, s. 154-157; ibidem, Program inauguracji obchodów XXX rocznicy wyzwolenia Opolszczyzny, s. 169-170. 
Związku Polskich Artystów Plastyków, Teatru, „Trybuny Opolskiej” oraz Rozgłośni Polskiego Radia. Zaproponowano w tym celu wymianę delegacji złożonych z przedstawicieli Wydziału Kultury KW PZPR, związków twórczych, dziennikarzy, przedstawicieli organizacji i instytucji aktywnych na polu kultury oraz działaczy artystycznego ruchu amatorskiego?.

Celem tej współpracy była wymiana informacji o działalności partii w dziedzinie upowszechniania oświaty i kultury oraz rozwoju gospodarki narodowej. Do końca listopada każdego roku komitety wojewódzkie miały wysyłać do Wydziału Organizacyjnego KC PZPR sprawozdania o realizacji rocznego planu oraz o politycznych i ekonomicznych efektach współpracy ${ }^{10}$.

Poza współpracą kulturalno-oświatową istniały również kontakty na płaszczyźnie sportowej i turystycznej. Przyczyniły się one do wymiany doświadczeń w rozwiązywaniu spraw szkoleniowych, zwłaszcza w organizacji treningów, przeprowadzania selekcji i badań sportowców. Doświadczenia z Czechosłowacji przenoszone były m.in. do nowo utworzonych na Opolszczyźnie szkół sportowych. Zapoczątkowano również organizowanie wspólnych obozów szkoleniowych. Współpracę organizacji młodzieżowych we własnym zakresie nawiązały Racibórz, Nysa i Prudnik z Opawą i Bruntalem w Czechosłowacji. Nie wykraczała ona jednak w początkowej fazie poza wymianę kilkuosobowych delegacji ${ }^{11}$. W następnych latach wypracowano już szczegółowy program współpracy między Bruntalem a Prudnikiem, której celem było kształtowanie i umacnianie przyjaźni między narodami Polski i Czechosłowacji12.

Przez kolejne lata w KW PZPR w Opolu wypracowywano i spisywano warunki współpracy z Czechosłowacką Republiką Socjalistyczną (CSRS). Miała się ona rozwijać na podstawie postanowień KC PZPR i KC KPCz. Programy współpracy

9 Zob. APO, Programy współpracy [z Komitetem Wojewódzkim Komunistycznej Partii Czechosłowacji w Czeskich Budziejowicach], sygn. 844, Pismo do Towarzysza Pawła Wojasa I Sekretarza KW PZPR, s. 33; ibidem, Plan kontaktów i wymiany KW PZPR Opole i Komitetem Wojewódzkim KPCz Ostrawa na rok 1963, s. 69-71.

10 Zob. APO, Materiały dotyczące współpracy, wymiany i kontaktów zagranicznych Komitetu Wojewódzkiego 1964-1971, sygn. 828, Pismo Wojewódzkiego Komitetu Frontu Jedności Narodu, s. 62; ibidem, Pismo I Sekretarza KW PZPR w Opolu, s. 116-120; APO, Materiały dotyczące współpracy, wymiany i kontaktów zagranicznych Komitetu Wojewódzkiego 1972-1973, sygn. 829, Sprawozdanie o współpracy z bratnimi partiami krajów socjalistycznych, s. 190-195; ibidem, Sprawozdanie z międzywojewódzkiej współpracy z krajami socjalistycznymi w latach 1972-1973, s. 202-205; APO, Materiały dotyczące współpracy, wymiany i kontaktów zagranicznych Komitetu Wojewódzkiego 1974-1975, sygn. 830, Sprawozdanie z kontaktów zagranicznych woj. opolskiego w 1974 r., s. 63-67; APO, Materiały dotyczące współpracy, wymiany i kontaktów zagranicznych Komitetu Wojewódzkiego - programy pobytu delegacji 1973-1974 sygn. 834, Sprawozdanie KW PZPR w Opolu z bratnimi partiami krajów socjalistycznych w latach 197475, s. $103-108$

11 Zob. APO, Materiały dotyczace współpracy, wymiany i kontaktów zagranicznych Komitetu Wojewódzkiego 1972-1973, sygn. 829, Informacja dot. kontaktów sportowych i turystycznych z krajami socjalistycznymi w latach 1972/73, s. 69; ibidem, Informacja o międzywojewódzkiej współpracy młodzieżowej z krajami socjalistycznymi w latach 1972/73, s. 86.

12 APO, Materiały dotyczace współpracy, wymiany i kontaktów zagranicznych Komitetu Wojewódzkiego 1974-1975, sygn. 830, Program współpracy między powiatami Bruntal (CSRS) oraz Prudnik (PRL) w roku 1974, s. 135-137. 
rozpisane były na poszczególne lata. W latach 80 . XX w. zakresie kultury uzgodniono wymianę przedstawicieli organizacji kulturalnych, zespołów i twórców na festiwalach, konfrontacjach teatralnych, plenerach malarskich. Odbywać się miały spotkania kierownictw wydziałów kultury obu województw celem oceny efektów tej współpracy w danym roku. Zgodnie z wytycznymi KW PZPR należało unikać wyjazdów o "charakterze ogólnym”, kontaktom osobowym miały towarzyszyć wystawy, prelekcje, koncerty, spotkania, dyskusje oraz zawarcie umów i porozumień o współpracy itd. ${ }^{13}$

Najszerszy zasięg miała współpraca, która koncentrowała się przede wszystkim na działalności kulturalno-oświatowej. Tu ważną rolę w Czechosłowacji odgrywał powstały w 1947 r. PZKO. Na Śląsku Opolskim organizacją pielęgnującą relacje z Polakami za Olzą było Towarzystwo Rozwoju Ziem Zachodnich (TRZZ14.

Rozkwit współpracy między społeczeństwem Śląska Opolskiego a Polakami na Zaolziu przyniosły jednak dopiero lata 70 . XX w. Materiały na ten temat znajdują się w Archiwum Związkowym PZKO w Czeskim Cieszynie, Archiwum Państwowym w Opolu oraz w Wojewódzkiej Bibliotece Publicznej im. E. Smołki w Opolu, gdzie zostały zdeponowane archiwalia dotyczące działalności Opolskiego Towarzystwa Kulturalno-Oświatowego (OTKO) ${ }^{15}$. Współpraca kulturalno-oświatowa z Zaolziem została bardzo dobrze udokumentowana przez periodyki społeczno-kulturalne, takie jak „Opole”, „Zwrot”, „Wczoraj, Dzisiaj, Jutro”, „Kalendarz Opolski”. W dwóch ostatnich z dokładnością niemal co do jednego dnia w kronikach towarzystw regionalnych opisane były wspólne działania, wyjazdy delegacji, wymiana zespołów artystycznych, wymiana wydawnictw.

Prezentowany artykuł stawia sobie za cel przybliżenie informacji na temat kontaktów kulturalnych społeczeństwa Śląska Opolskiego z Polakami żyjącymi na Zaolziu w latach 1970-1990. Odwołuje się do wspomnianej prasy regionalnej, której relacje zostały uzupełnione o dokumenty OTKO, AZ PZKO oraz APO.

$$
\text { * * * * }
$$

13 APO, Programy współpracy [z Komitetem Wojewódzkim Komunistycznej Partii Czechosłowacji w Czeskich Budziejowicach], sygn. 844, Zasady i warunki wymiany kulturalnej z Czeskimi Budziejowicami (CSRS), s. 1

14 Towarzystwo Rozwoju Ziem Zachodnich - organizacja społeczna, powołana 26 V 1957 r. prowadziła badania i propagowała tematykę Ziem Zachodnich i Północnych („Ziem Odzyskanych”), uzasadniając prawa państwa polskiego do tych ziem i integracji tzw. Ziem Odzyskanych z pozostałymi obszarami kraju. Została rozwiazzana w grudniu 1970 r. Zob. Statut Towarzystwa Rozwoju Ziem Zachodnich, Warszawa 1957; Ziemie odzyskane. Ziemie zachodnie. Zadania programowe Towarzystwa Rozwoju Ziem Zachodnich, oprac. zespół pod kier. W. Lechowicza, Poznań-Warszawa 1958; TRZZ na Opolszczyźnie 1957-1970, oprac. R. Hładko, Opole 1970; Działalność Towarzystwa Rozwoju Ziem Zachodnich w latach 1957-1970, oprac. red. F. Hawranek, Warszawa- Wrocław 1973.

15 Opolskie Towarzystwo Kulturalno-Oświatowe - organizacja społeczna, powołana w listopadzie 1970 r., jej celem było wspieranie i upowszechnianie kultury regionalnej i twórczości ludowej oraz inicjatyw społecznych w zakresie pracy kulturalno-oświatowej i badań naukowych na terenie Śląska; wydawała kwartalnik „Wczoraj, Dzisiaj, Jutro” i rocznik „Kalendarz Opolski”. OTKO jest obecnie (2017 r.) w likwidacji. Zob. Statut Opolskiego Towarzystwa Kulturalno-Oświatowego, [b.m] [b.d]; Materiały na III Zjazd Delegatów Opolskiego Towarzystwa Kulturalno-Oświatowego, Opole 1978; Materiały na IV Zjazd OTKO, Opole 1983; VI Zjazd OTKO, Opole 1991 
Zarząd Wojewódzki TRZZ podczas spotkania w dniu 6 listopada 1970 r. przyjął uchwałę w sprawie wystąpienia delegatów wojewódzkiej organizacji TRZZ na Zjeździe Krajowym z wnioskiem o rozwiązanie TRZZ. Jednocześnie stwierdzono, że w szeregach TRZZ działał „liczny, ofiarny i doświadczony aktyw”, który w latach następnych powinien brać czynny udział w życiu społeczno-kulturalnym. W związku z powyższym Zarząd Wojewódzki TRZZ wystąpił do Wojewódzkiego Komitetu FJN z wnioskiem o powołanie do życia nowego towarzystwa społeczno-kulturalnego, którego celem byłoby opracowanie całościowego programu pracy społeczno-kulturalnej w Opolskiem. Równocześnie Plenum TRZZ zawróciło się do członków $\mathrm{z}$ apelem o masowe wspieranie działalności nowego towarzystwa oraz o udział w pracy innych organizacji społeczno-politycznych, a zwłaszcza towarzystw regionalnych ${ }^{16}$. Nowo powstała w listopadzie 1970 r. jednostka przyjęła nazwę: Opolskie Towarzystwo Kulturalno-Oświatowe. Na posiedzeniu Zarządu OTKO 1 grudnia 1970 r. przyjęto Statut Towarzystwa. Przewodniczącym OTKO został Ryszard Hajduk, a zastępcami: Karol Musioł, Zygmunt Nowak i Franciszek Adamiec ${ }^{17}$.

W związku z likwidacją z dniem 1 stycznia $1971 \mathrm{r}$. TRZZ, OTKO podjęło się kontynuacji wypracowanych przez TRZZ kierunków i form działania, szczególnie w zakresie upowszechniania wiedzy o Opolszczyźnie oraz popularyzacji „tradycji walk o polskość Śląska Opolskiego"18. Głównym celem działalności OTKO stało się rozwijanie działalności kulturalno-oświatowej poprzez popularyzację dorobku regionu, ukazywanie roli i miejsca Śląska Opolskiego, popularyzowanie badań naukowych na Śląsku oraz popieranie i upowszechnianie kultury regionalnej i twórczości ludowej ${ }^{19}$.

Działalność OTKO bardzo dobrze współgrała z celami PZKO, który skupiał się przede wszystkim na wspieraniu kultury i oświaty poprzez nawiązywanie do tradycji kultury polskiej, tradycji kultury Śląska Cieszyńskiego, na utrzymywaniu powszechnego używania języka polskiego i promocji kultury polskiej w Czechosłowacji oraz wspieraniu polskich inicjatyw społecznych i kulturalnych.

Pod koniec 1971 r. próbę nawiązania kontaktów ze środowiskiem kulturalno-oświatowym Opolszczyzny podjęły również władze PZKO w Czechosłowacji. Współpraca OTKO poprzez towarzystwa regionalne i instytucje Opolszczyzny z kołami i sekcjami PZKO polegać miała m.in. na: wymianie delegacji, sesjach naukowych i innych imprezach masowych, wymianie wydawnictw, zespołów artystycznych oraz organizowaniu wystaw plastycznych, prowadzeniu na terenie Czechosłowacji przez specjalistów kursów dla działaczy kulturalnych z zakresu reżyserii, scenografii i choreografii, a także umożliwieniu działaczom PZKO zwiedzenia Śląska

16 Wojewódzka Biblioteka Publiczna w Opolu (WBP Opole), Protokoły z posiedzeń Prezydium Zarządu OTKO i Zarządu OTKO 1970 i 1971 r., sygn. 8, Uchwała Plenum Zarządu Wojewódzkiego Towarzystwa Rozwoju Ziem Zachodnich powzięta w dniu 6 XI 1970 r., s. 1.

17 WBP Opole, Protokoły z posiedzeń Prezydium Zarządu OTKO i Zarządu OTKO 1970 i 1971 r., sygn. 8 , Protokół 1/70, s. 1-2.

18 Nasz pierwszy Zjazd, „Wczoraj, Dzisiaj, Jutro”, R. VI (1972), nr 2/19, s. 4. 
Opolskiego ${ }^{20}$. Współpraca ta prowadzić miała również do umocnienia kontaktów Polaków z Zaolzia z ojczyzną, utrwalając jednocześnie przekonanie, że społeczeństwo polskie nie zapomina o swoich rodakach poza granicami kraju. Zainteresowanie Polaków mieszkających w Czechosłowacji kontaktami z krajem było bardzo duże. Na Opolszczyźnie zrodziło się przekonanie, że utrzymanie więzi z Polakami mieszkającymi na Śląsku Cieszyńskim powinno być sprawą bliską każdemu towarzystwu regionalnemu w Opolskiem ${ }^{21}$. W związku z tym z inspiracji OTKO niektóre towarzystwa regionalne Opolszczyzny podjęły współpracę z kołami PZKO w Czechosłowacji.

Kontakty władz i społeczeństwa Śląska Opolskiego z Polakami na Zaolziu istniały na wielu płaszczyznach począwszy od osobistych więzi władz Śląska Opolskiego oraz przedstawicieli OTKO i PZKO, poprzez współdziałanie towarzystw regionalnych i kół PZKO po współpracę w dziedzinie kultury, szczególnie zaś w zakresie prasy, literatury, wystaw, festiwali i teatru. Kontakty te poszerzały się z każdym rokiem o cenne, wzajemne doświadczenia i przedsięwzięcia, m.in. o wycieczki do ciekawych zakątków Polski, rajdy rowerowe i piesze, czy też wymianę zespołów artystycznych ${ }^{22}$.

Kontaktami z Polakami na Zaolziu zajmowała się Komisja ds. Łączności z Zagranicą, która na II Zjeździe OTKO przyjęła nazwę Komisja Współpracy z Zagranicą ${ }^{23}$.

\section{Kontakty władz Śląska Opolskiego oraz przedstawicieli OTKO i PZKO} Władze Śląska Opolskiego oraz OTKO często uczestniczyły w jubileuszach PZKO. Doskonałą okazją ku temu było m.in. 25-lecie działalności Zarządu Głównego PZKO w Czechosłowacji. Uroczystości te odbyły się w czerwcu 1972 r. w Karwinie. Wśród licznych delegacji stowarzyszeń kulturalnych z Polski znajdowali się również na tej imprezie przedstawiciele OTKO: Bernard Waleński - sekretarz i Roman Sękowski - członek Zarządu. W czasie uroczystego plenum Zarządu Głównego PZKO minister finansów CSRS Leopold Lér przekazał na ręce przewodniczącego Zarządu Głównego PZKO Eugeniusza Suchanka „Order Pracy”, odznaczenie przyznane zostało Związkowi przez prezydenta Ludvíka Svobodę „za wybitne osiągnięcia w rozwoju polsko-czechosłowackiej przyjaźni oraz za zasługi w rozwoju kultury w regionie zaolziańskim" ${ }^{24}$.

Corocznie odbywały się wspólne posiedzenia Zarządu OTKO z przedstawicielami Zarządu Głównego PZKO w Polsce i w Czechosłowacji, na których dokonywano oceny dotychczasowej współpracy oraz omawiano plany współdziałania na następne 
lata ${ }^{25}$. Na posiedzeniach Zarządu OTKO składano również sprawozdania z przebiegu wizyt w Czeskim Cieszynie i delegacji PZKO w Opolu.

Podczas pobytu na Opolszczyźnie delegacja PZKO była przyjmowania także przez regionalne władze. W październiku 1973 r. na zaproszenie OTKO przebywał na Opolszczyźnie sekretarz Zarządu Głównego PZKO Henryk Szmeja, który przewodniczył delegacji. Przyjął ich sekretarz Komitetu Wojewódzkiego PZPR dr Józef Gruszka. Goście spotkali się także z przedstawicielami Wojewódzkiego Komitetu FJN i Prezydium OTKO. Dokonano oceny dotychczasowej współpracy oraz omówiono możliwości dalszego współdziałania PZKO z OTKO, towarzystwami regionalnymi, instytucjami i placówkami kulturalnymi, związkami twórczymi i redakcjami.

Z rewizytą na Zaolziu w grudniu 1973 r. przebywała delegacja OTKO w składzie: przewodniczący - Artur Gadziński, zastępca przewodniczącego - Franciszek Adamiec, sekretarz - Bernard Waleński i członek Zarządu - Roman Sękowski. W skład delegacji wchodził również przedstawiciel Wydziału Propagandy i Agitacji KW PZPR Zbigniew Domański. W trakcie pobytu delegacja spotkała się z kierownictwem Zarządu Głównego PZKO, przedstawicielami kół PZKO współpracującymi z polskimi towarzystwami regionalnymi, zapoznała się z działalnością polskiej biblioteki w Karwinie oraz Klubu Propozycji w Czeskim Cieszynie, ponadto gościła w Polskim Gimnazjum w Czeskim Cieszynie. Uczestniczyła również w zebraniu Zarządu Głównego PZKO. Efektem tego pobytu było zacieśnienie współpracy między OTKO a PZKO na następne lata. Oprócz dotychczasowej współpracy postanowiono pomóc placówkom oświatowym na Zaolziu, organizując wycieczki nauczycieli polskich z Zaolzia do placówek oświatowych na Opolszczyźnie, zaopatrując szkoły w pomoce naukowe i lektury, zwiększając liczbę odczytów o PZKO na Opolszczyźnie i o Opolszczyźnie na Zaolziu, kontynuując wymianę zespołów artystycznych ${ }^{26}$. W dalszym ciągu Wojewódzka i Miejska Biblioteka Publiczna (WiMBP) przekazywać miała do PZKO nowości książkowe, natomiast OTKO miało systematycznie przekazywać do Zarządu Głównego PZKO nowości repertuarowe dla zespołów teatralnych i muzycznych. Nadal WiMBP miała prenumerować miesięcznik PZKO „Zwrot” oraz pisma młodzieżowe. Natomiast Zarząd Oddziału Stowarzyszenia Dziennikarzy Polskich (SDP) miał zapewnić stały dopływ artykułów opolskich dziennikarzy do Redakcji „Zwrotu”27.

W czasie pobytu w Opolu w styczniu 1974 r. delegaci Zarządu Głównego PZKO Emil Sztabla i Bogumił Branny odbyli wiele spotkań w różnych instytucjach, omawiając

25 WBP Opole, Protokoły z posiedzeń Prezydium Zarządu OTKO i Zarządu OTKO 1972 r., sygn. 9, Opolskie Towarzystwo Kulturalno-Oświatowe - działalność w okresie listopad 1970-luty 1972 - program działania na lata 1972-1974, s. 2.

26 WBP Opole, Protokoły z posiedzeń Prezydium Zarządu 1973, 1974, sygn. 20, Polska Zjednoczona Partia Robotnicza Komitet Wojewódzki w Opolu Wydział Propagandy i Agitacji, s. 1-4; por. Kronika opolskiego ruchu regionalnego (październik 1973-styczeń 1974), „Wczoraj, Dzisiaj, Jutro”, R. VIII (1974), nr 1/26, s. 87 .

27 WBP Opole, Protokoły z posiedzeń Prezydium Zarządu 1973, 1974, sygn. 20, Informacja o przebiegu spotkania z delegacją Polskiego Zwiazku Kulturalno-Oświatowego z Czechosłowacji, s. 1-3; zob. Opolska Kronika Kulturalna (kwiecień-październik 1973 roku), oprac. B. Waleński, „Wczoraj, Dzisiaj, Jutro”,

R. VII (1973), nr 3-4/24-25, s. 114. 
możliwości realizacyjne szeregu przedsięwzięć. Spotkali się z przewodniczącym i sekretarzem WK FJN Ryszardem Hajdukiem i Eugeniuszem Brudkiewiczem, dyrektorem Filharmonii Opolskiej Tadeuszem Traczem, redaktorami miesięcznika "Opole" Edwardem Pochroniem, Janem Goczołem i Markiem Jodłowskim oraz dyrektorem WiMBP Romanem Sękowskim. W spotkaniach tych brał udział przewodniczący OTKO Artur Gadziński i inni członkowie towarzystwa ${ }^{28}$.

Z kolei w czerwcu tego roku przebywała na Opolszczyźnie 42-osobowa delegacja PZKO z Czechosłowacji. Goście zapoznali się z dorobkiem OTKO i zwiedzili Opolszczyznę. W ramach współpracy z PZKO choreograf Emilia Upirów z ramienia OTKO prowadziła na terenie Czechosłowacji dla 23 osób szkolenie z choreografii tańców regionalnych. Słuchaczami byli instruktorzy placówek kulturalnych ${ }^{29}$.

Pod koniec 1974 r. przebywała w Czechosłowacji delegacja Zarządu OTKO w składzie: Artur Gadziński - przewodniczący Zarządu, Eugeniusz Brudkiewicz - zastępca przewodniczącego, Andrzej Ciunkiewicz - sekretarz Zarządu. Dokonano wówczas oceny dotychczasowej współpracy między towarzystwami regionalnymi Opolszczyzny a kołami PZKO w Czechosłowacji. Na posiedzeniu Zarządu OTKO Józef Krotiuk - wicewojewoda opolski - poinformował, że Urząd Wojewódzki w Opolu przekaże do OTKO pieniądze na zakup wydawnictw przeznaczonych dla polskich bibliotek w Czechosłowacji ${ }^{30}$.

W następnym roku delegacja OTKO uczestniczyła w posiedzeniu Zarządu Głównego PZKO, na którym na ręce przewodniczącego Zarządu PZKO Stanisława Kondziołki wręczono - przyznany na wniosek OTKO - Medal 30-lecia Polski Ludowej za aktywne działanie „na rzecz pogłębienia współpracy”31.

W lipca 1975 r. w województwach opolskim i wrocławskim przebywali członkowie PZKO i ich rodziny. Zwiedzili oni Opole, skansen w Bierkowicach, Nysę, Brzeg, Otmuchów oraz Kudowę-Zdrój i Wrocław ${ }^{32}$.

W następnym roku delegacja OTKO (Franciszek Adamiec, Andrzej Ciunkiewicz i Bernard Waleński) gościła w Czechosłowacji. W czasie wizyty posumowano dotychczasową współpracę i omówiono zamierzenia na kolejne lata. Delegacja OTKO zapoznała się z działalnością Koła w Oldrzychowicach i zwiedziła wystawę malarzy-amatorów członków

28 Kronika opolskiego ruchu regionalnego (październik 1973-styczeń 1974), „Wczoraj, Dzisiaj, Jutro”, R. VIII (1974), nr 1/26, s. 89.

29 Kronika ruchu regionalnego; Opolskie Towarzystwo Kulturalno-Oświatowe, oprac. A. Ciunkiewicz, „Wczoraj, Dzisiaj, Jutro”, R. VIII (1974), nr 4/29, s. 63.

30 WBP Opole, Protokoły z posiedzeń Prezydium i Zarządu OTKO 1975-1976, sygn. 52, Protokół nr 1 z posiedzenia Prezydium Zarządu Opolskiego Towarzystwa Kulturalno-Oświatowego w Opolu odbytego w dniu 2 I 1975 r., s. 2.

31 Kronika Opolskiego Towarzystwa Kulturalno-Oświatowego. Kronika ruchu regionalnego, oprac. A. Ciunkiewicz, „Wczoraj, Dzisiaj, Jutro”, R. IX (1975), nr 1/30, s. 109-110.

32 Kronika Opolskiego Towarzystwa Kulturalno-Oświatowego za okres od lipca do września 1975 r. Kronika ruchu regionalnego, oprac. A. Ciunkiewicz, „Wczoraj, Dzisiaj, Jutro”, R. IX (1975), nr 4/33, s. 48-49. 
PZKO $^{33}$. W lipca 1976 r. ponownie przebywała w Czeskim Cieszynie delegacja OTKO w składzie: Andrzej Ciunkiewicz - sekretarz OTKO i Władysław Bartkiewicz ${ }^{34}$ - dyrektor Estrady Opolskiej. Celem tej wizyty było omówienie dotychczasowej współpracy oraz ustalenie możliwości występów w Polsce zespołów folklorystycznych Zarządu Głównego PZKO. Ze strony PZKO w rozmowach udział wzięli: Stanisław Kondziołka - prezes, Bogdan Kisza - wiceprezes i Henryk Szmeja - sekretarz Zarządu Głównego. Podczas tego pobytu delegacja OTKO uczestniczyła w festynie górskim w Kosarzyskach ${ }^{35}$.

W stycznia 1977 r. do Opola przyjechał Stanisław Kondziołka i Henryk Szmeja, którzy spotkali się z przewodniczącym OTKO Ryszardem Hajdukiem i przedstawicielami Zarządu, dyskutowano o kierunkach współpracy na rok 1978. Na spotkaniu u dyrektora Wydziału Kultury i Sztuki Urzędu Wojewódzkiego z dyrektorami instytucji kulturalnych i związków twórczych rozmawiano o poszerzeniu dotychczasowych kontaktów z Biurem Wystaw Artystycznych (BWA), plastykami, literatami, bibliotekarzami i aktorami ${ }^{36}$. W kolejnych latach nawiązana została ściślejsza współpraca między Biblioteką Wojewódzką w Opolu a Biblioteką w Karwinie (CSRS), Związkiem Polskich Artystów Plastyków z analogicznym związkiem w Cieszynie (CSRS) ${ }^{37}$.

Z rewizytą w Czechosłowacji w marcu 1977 r. przebywała delegacja OTKO - Karol Musioł i Tadeusz Soroczyński, którzy złożyli kwiaty pod pomnikiem Żwirki i Wigury w Cierlicku, a w Żywocicach odwiedzili cmentarz z grobami 32 Polaków zamordowanych przez faszystów w 1944 r. ${ }^{38}$ Pod koniec miesiąca przedstawiciele Komisji Współpracy z Zagranicą spotkali się w Opolu z delegacją Zarządu Głównego PZKO: Emilem Sztablą, Bronisławem Bielanem i Bronisławem Firlą. Omawiano wówczas zasady i kierunki dalszej współpracy w dziedzinie kultury i oświaty. W rozmowach tych zwrócono przede wszystkim uwagę na potrzebę ożywienia łączności pomiędzy kołami PZKO a OTKO i Komisją Współpracy z Zagranicą oraz poszczególnymi towarzystwami

33 WBP Opole, Protokoły z posiedzeń Prezydium Zarządu 1973, 1974, sygn. 52, Protokół Nr 2 z posiedzenia Prezydium Zarządu Opolskiego Towarzystwa Kulturalno-Oświatowego odbytego w dniu 31 III 1976 r., s. 1.

34 Władysław Bartkiewicz (1932-2009) - współtwórca i organizator festiwali opolskich. W latach 19631994 był dyrektorem i szefem programowym festiwali opolskich. Przez 35 lat kierował Estradą Opolska która organizowała festiwale polskiej piosenki. Dnia 11 XI 2008 r. otrzymał tytuł „Zasłużonego Obywatela Miasta Opola".

35 WBP Opole, Protokoły z posiedzeń Prezydium i Zarządu OTKO 1975-1976, sygn. 52, Protokół z posiedzenia Prezydium Zarządu Opolskiego Towarzystwa Kulturalno-Oświatowego w Opolu odbytego w dniu 12 VII 1976 r., s. 2; por. Kronika Opolskiego Towarzystwa Kulturalno-Oświatowego za okres od 1.07. do 30.09. 1976 r. Kronika ruchu regionalnego, oprac. A. Ciunkiewicz, „Wczoraj, Dzisiaj, Jutro”, R. X (1976), nr $4 / 37$, s. 74

36 WBP Opole, Dokumenty dot. III Zjazdu OTKO 1978, sygn. 77, III Zjazd delegatów Opolskiego Towarzystwa Kulturalno-Oświatowego. Materiały, s. 20.

37 APO, Materiały dotyczące współpracy, wymiany i kontaktów zagranicznych Komitetu Wojewódzkiego 1976-1977, sygn. 831, Program współpracy z zagranicą na rok 1977, s. 150-156.

38 WBP Opole, Protokoły z posiedzeń Prezydium Zarządu i Zarządu OTKO 1976-1977-1978, sygn. 74 Informacja - Sprawozdanie Komisji ds. Współpracy z Polonią Zagraniczną przy Opolskim Towarzystwie Kulturalno-Oświatowym, s. 2. 
regionalnymi w województwie opolskim. W Klubie Związków Twórczych w Opolu otwarto wystawę Bronisława Firli zatytułowaną "Dachy i wieże miast polskich”. Opolscy plastycy podpisali również porozumienie o współpracy z polskim środowiskiem plastycznym w Czechosłowacji ${ }^{39}$. W jubileuszowych obchodach 30-lecia działalności PZKO w Czechosłowacji w maju tegoż roku wzięła również udział delegacja OTKO - Joanna Kuśnierz, Ryszard Ambros i Jerzy Lipka ${ }^{40}$.

Spotkania poświęcone współpracy z Polakami na Zaolziu odbywały się także w Towarzystwie Łączności z Polonią „Polonia” w Warszawie. Z narady w grudniu 1977 r. Joanna Kuśnierz, sekretarz Komisji Współpracy z Zagranica, złożyła sprawozdanie na posiedzeniu Zarządu OTKO. Wynikało z niego, że w planach na przyszłość należałoby uwzględnić m.in. zaproszenie Sceny Polskiej Teatru Cieszyńskiego do Opola, ponadto zauważono, że książka polska na Zaolziu jest bardzo wysoko ceniona, należy zatem wysyłać do PZKO polskie wydawnictwa, nuty, śpiewniki, oraz zaproponowano zorganizowanie wystawy fotograficznej poświęconej Opolszczyźnie i miastu Opole ${ }^{41}$.

Współpraca OTKO z PZKO nabrała większego rozmachu w 1978 r., do czego bez wątpienia przyczyniło się zacieśnienie osobistych kontaktów między działaczami obydwu organizacji ${ }^{42}$. W roku tym odbyło się znacznie więcej spotkań z polskimi społecznikami z Zaolzia niż w poprzednich latach. W styczniu odwiedzili Opole Stanisław Kondziołka i Henryk Szmeja. Spotkali się m.in. z przewodniczącym OTKO Ryszardem Hajdukiem oraz z przedstawicielami Prezydium Zarządu OTKO, Komisją Współpracy z Zagranicą, następnie - z dyrektorem Wydziału Kultury i Sztuki Urzędu Wojewódzkiego w Opolu Eugeniuszem Broczkowskim. Rozmowy dotyczyły poszerzenia dotychczasowego współdziałania z PZKO. Podczas pobytu w Opolu delegacja Zarządu Głównego PZKO złożyła też wizytę Eugeniuszowi Brudkiewiczowi, kierownikowi Wydziału Pracy Ideowo-Wychowawczej KW PZPR. Przedstawiciele Zarządu Głównego PZKO odwiedzili towarzystwa regionalne i placówki kulturalne w Brzegu, Grodkowie, Prudniku i Opolu. Przeprowadzili w tych miastach rozmowy o możliwościach nawiązania lub poszerzenia współpracy. Poza tym zapoznali się z twórczością ludową na Śląsku Opolskim ${ }^{43}$, omówili formy i zakres współdziałania

39 Ibidem, s. 1-2; zob. (s), Opolskie Towarzystwo Kulturalno-Oświatowe. Kronika ruchu regionalnego I kwartał 1977, „Wczoraj, Dzisiaj, Jutro”, R. XI (1977), nr 2/39, s. 74.

40 T. Soroczyński, Opolskie Towarzystwo Kulturalno-Oświatowe. Kronika ruchu regionalnego II kwartał 1977, „Wczoraj, Dzisiaj, Jutro”, R. XI (1977), nr 3/40, s. 94.

41 WBP Opole, Protokoły z posiedzeń Prezydium Zarządu i Zarządu OTKO 1976-1977-1978, sygn. 74, Protokół z posiedzenia Zarządu Opolskiego Towarzystwa Kulturalno-Oświatowego w Opolu odbytego w dniu 28 XII 1977 r., s. 3-4

42 Zob. APO, Materiały dotyczące współpracy, wymiany i kontaktów zagranicznych Komitetu Wojewódzkiego 1978, sygn. 832, Sprawozdanie z przebiegu współpracy z zagranica w 1978 r., s. 14; WBP Opole, Protokoły z posiedzeń Prezydium Zarządu OTKO i Zarządu OTKO 1979 r., sygn. 95, Kontakty Opolskiego Towarzystwa Kulturalno-Oświatowego z Polakami z Polskiego Związku Kulturalno-Oświatowego w Czechosłowacji (1978), s. 1.

43 WBP Opole, Protokoły z posiedzeń Przezydium Zarządu OTKO i Zarządu OTKO 1979 r., sygn. 95, Kontakty Opolskiego Towarzystwa Kulturalno-Oświatowego z Polakami z Polskiego Związku Kulturalno-Oświatowego w Czechosłowacji (1978), s. 2. 
w roku 1978. Na zakończenie wizyty delegacja z PZKO gościła w opolskiej „Cepelii”, gdzie podziwiała wyroby rękodzieła artystycznego ${ }^{44}$.

W roku 1979 współpraca polsko-czechosłowacka na terenach przygranicznych nie była najlepsza. Pomimo prób nawiązania bliższych kontaktów z władzami czechosłowackimi nie udało się tej sprawy sfinalizować ze względu na brak większego zainteresowania tych władz. Strona czechosłowacka twierdziła, że „sami powinniśmy nawiązać kontakty z wybranym przez siebie województwem czechosłowackim"45. Pod koniec listopada 1979 r. udało się jednak zaprosić na Opolszczyznę Stanisława Kondziołkę i Henryka Szmeję. Podczas spotkania z kierownictwem OTKO omówiono problemy współdziałania kół PZKO z opolskimi towarzystwami regionalnymi. Goście zwiedzili Górę św. Anny, Leśnicę i Zdzieszowice ${ }^{46}$.

Na zaproszenie OTKO w marcu 1980 r. przebywali na Opolszczyźnie Wilhelm Przeczek i Kazimierz Kaszper - literaci, członkowie Sekcji Literacko-Artystycznej (SLA) przy PZKO w Czeskim Cieszynie. Goście zostali przyjęci przez przewodniczącego OTKO, Ryszrda Hajduka, rozmawiali z członkami Komisji Współpracy z Zagranicą i z młodzieżą zrzeszoną w Kole Młodych przy opolskim Oddziale Związku Literatów Polskich (ZLP), wzięli również udział w seminarium literackim zorganizowanym przez Związek Nauczycieli Polskich (ZNP) ${ }^{47}$.

We wrześniu 1981 r. Wydział Kultury i Sztuki Urzędu Wojewódzkiego oraz OTKO zaprosili do Opola delegację Zarządu Głównego PZKO z Czeskiego Cieszyna (Stanisława Kondziołkę, Henryka Szmeję, Kazimierza Ferfeckiego i Eugeniusza Hyrnika). Na spotkaniu Komisji Współpracy z Zagranicą goście zza Olzy omawiali aktualne kierunki współpracy z poszczególnymi organizacjami, skorygowano też plany na rok 1982. Delegacja została przyjęta przez wicewojewodę opolskiego Mieczysława Morytę oraz zwiedziła Oddział WBP w Rogowie Opolski ${ }^{48}$. Natomiast na spotkaniu z przedstawicielami wojewódzkich placówek kulturalnych podejmowano kwestie pomocy dla kół PZKO w zakresie wydawnictw, plastyki oraz twórczości amatorskiej ${ }^{49}$.

Ze względu na ogłoszenie stanu wojennego w grudniu 1981 r., w następnym roku kontakty z Zarządem Głównym PZKO były sporadyczne i ograniczały się przede

44 WBP Opole, Protokoły z posiedzeń Prezydium Zarządu i Zarządu OTKO 1976-1977-1978, sygn. 74 Protokół z posiedzenia Prezydium Zarządu Opolskiego Towarzystwa Kulturalno-Oświatowego w Opolu odbytego w dniu 8 II 1978 r., s. 2-3; por. T. Soroczyński, Opolskie Towarzystwo Kulturalno-Oświatowe. Kronika ruchu regionalnego, „Wczoraj, Dzisiaj, Jutro”, R. XI (1978), nr 2/43, s. 80.

45 APO, Materiały dotyczace współpracy, wymiany i kontaktów zagranicznych Komitetu Wojewódzkiego 1979, sygn. 833, Sprawozdanie z prowadzonej w 1979 r. współpracy zagranicznej przez Urząd Wojewódzki w Opolu, s. 16, 19.

46 Materiały na IV Zjazd OTKO, Opole 1983, s. 43; por.. T. Soroczyński, Opolskie Towarzystwo Kulturalno-Oświatowe. Kronika ruchu regionalnego, „Wczoraj, Dzisiaj, Jutro”, R. XIV (1980), nr 1/50, s. 87.

47 Materiały na IV Zjazd OTKO, ..., s. 44.

48 T. Soroczyński, Opolskie Towarzystwo Kulturalno-Oświatowe. Kronika ruchu regionalnego, „Wczoraj, Dzisiaj, Jutro", R. XV (1981), nr 4/57, s. 78

49 Kronika społeczno-kulturalna Ślqska Opolskiego wrzesień 1981-sierpień 1982, oprac. T. Soroczyński „Kalendarz Opolski” 1983, Opole 1983, s. 169. 
wszystkim do wymiany korespondencji i wydawnictw. Udało się jednak zorganizować w lipcu 1982 r. w Klubie Międzynarodowej Prasy i Książki (KMPiK) w Opolu spotkanie z redaktorem Kazimierzem Kaszperem, który wygłosił prelekcję o życiu kulturalnym Polaków na Zaolziu ${ }^{50}$.

Okazją do kolejnego spotkania był jubileusz 35-lecia działalności PZKO w Czechosłowacji. Podczas IV Zjazdu OTKO Henryk Szmeja - sekretarz Zarządu Głównego PZKO - przedstawił referat o działalności PZKO. Dziękując za współpracę OTKO z Zarządem i kilku towarzystw regionalnych z kołami PZKO, wyraził nadzieję, że "osłabione" kontakty znów się ożywią ${ }^{51}$. W następnych latach wzajemne relacje „przybrały na sile”.

W XIV Zjeździe PZKO w Czeskim Cieszynie w 1984 r. uczestniczyła delegacja OTKO: Franciszek Adamiec - przewodniczący i Eugeniusz Broczkowski - członek Prezydium Zarządu OTKO ${ }^{52}$. We wrześniu tegoż roku z kolei w Opolu przebywali Władysław Orszulik, pierwszy sekretarz Zarządu Głównego PZKO i Emil Sztabla, kierownik pionu ekonomicznego Zarządu Głównego PZKO. Celem wizyty było wyznaczenie ram współpracy między OTKO i PZKO. Goście z Zaolzia spotkali się z członkami komisji problemowych OTKO. Dyskusja dotyczyła życia polskiej grupy narodowościowej w Czechosłowacji oraz działalności PZKO ${ }^{53}$.

W połowie 1985 r. przebywał na Opolszczyźnie Władysław Młynek, nauczyciel polskiej szkoły w Milikowie, kierownik artystyczny zespołu „Gorol”, poeta i działacz PZKO. Spotkanie w Klubie Akademickim Wyższej Szkoły Pedagogicznej ze studentami i członkami Polskiego Towarzystwa Ludoznawczego dotyczyło kultury Śląska Cieszyńskiego po obydwóch stronach Olzy ${ }^{54}$.

Kolejny jubileusz PZKO (40-lecie działalności) został również „zauważony” w Opolu. Z tej z okazji wojewoda opolski złożył na ręce Stanisława Kondziołki - przewodniczącego PZKO życzenia oraz „wyrazy uznania za szlachetną pasję w krzewieniu polskiego słowa, polskiej kultury i oświaty na Zaolziu. Miejsce i rola Związku z jego działaczami stanowi ważny element w rozwoju przyjaźni polsko-czechosłowackiej”落. Przekazał również OTKO „serdeczne gratulacje wraz życzeniami satysfakcji w bezinteresownej pracy na rzecz tożsamości narodowej, krzewienia polskiego

50 WBP Opole, Sprawozdania, programy, plany pracy 1983, 1984, sygn. 110, Działalność Opolskiego Towarzystwa Kulturalno-Oświatowego w 1982 r., s. 7; por. Materiały na IV Zjazd OTKO, Opole 1983, s. 46.

51 M. Karp, Z troskq o dobra najwyższe i ... najbliższe, „Wczoraj, Dzisiaj, Jutro”, R. XVII (1983), nr 2-3/83, s. 30-31.

52 Kronika społeczno-kulturalna Ślaska Opolskiego wrzesień 1982-sierpień 1983, oprac. T. Soroczyński, „Kalendarz Opolski” 1984, Opole 1984, s. 220.

53 Kronika społeczno-kulturalna wrzesień 1984-sierpień 1985, oprac. T. Soroczyński, „Kalendarz Opolski" 1986, Opole 1986, s. 213.

54 Ibidem, s. 226.

55 AZ PZKO, Wojewoda Opolski, sygn. 1517-530, Życzenia z okazji 40-lecia PZKO z dnia 12 XI 1986 r. 
słowa i polskiej kultury”56 oraz przyznał z okazji tego jubileuszu Medal „W 40 rocznicę powrotu Śląska Opolskiego do Macierzy” za „upowszechnianie kultury i oświaty narodowej, krzewienie przyjaźni polsko-czechosłowackiej, długoletnią owocną współpracę z opolskim regionem" ${ }^{57}$.

We wrześniu 1983 r. Kazimierz Kaszper, poeta i dziennikarz „Głosu Ziemi Cieszyńskiej", spotkał się ze słuchaczami Studium Kulturalno-Oświatowego i Bibliotekarskiego w Opolu, mówił o literaturze i polskim życiu kulturalnym na Zaolziu ${ }^{58}$.

Na zaproszenie OTKO przebywała na Opolszczyźnie w listopadzie 1983 r. delegacja Zarządu Głównego PZKO w składzie: dr Stanisław Kondziołka - przewodniczący PZKO, redaktor naczelny „Głosu Ludu”, Władysław Orszulik - sekretarz generalny PZKO oraz Rudolf Popiołek - członek Prezydium. Podczas spotkania z kierownictwem OTKO rozmawiano o kierunkach i formach współpracy między obiema organizacjami w ostatnich latach. Goście zza Olzy spotkali się również z kierownictwem Towarzystwa Przyjaciół Opola (TPO), zwiedzili Opole oraz złożyli kwiaty na grobach byłych przewodniczących OTKO - Artura Gadzińskiego i Ryszarda Hajduka. W Wydziale Kultury i Sztuki Urzędu Wojewódzkiego delegacja PZKO rozmawiała także z przedstawicielami wojewódzkich instytucji kulturalnych, ustalając kierunki współpracy ${ }^{59}$.

W październiku 1984 r. przebywali w Opolu Władysław Orszulik i Emil Sztabla. Celem wizyty było ustalenie kierunków współpracy między OTKO i PZKO na rok następny. Goście z Zaolzia spotkali się z członkami komisji problemowych OTKO. Dyskusja dotyczyła życia polskiej grupy narodowościowej w Czechosłowacji i działalności PZKO ${ }^{60}$.

Dnia 19 grudnia 1984 r. w Czeskim Cieszynie została podpisana umowa o współpracy pomiędzy Zarządem Głównym PZKO i OTKO. Umowę z ramienia OTKO podpisali: Franciszek Adamiec, Michał Jaworski, zastępca dyrektora Wydziału Kultury i Sztuki Urzędu Wojewódzkiego i Tadeusz Soroczyński, sekretarz OTKO. Podczas posiedzenia Prezydium Zarządu Głównego PZKO Franciszek Adamiec i Tadeusz Soroczyński otrzymali złote odznaki PZKO „Zasłużony dla Związku”61.

Na początku 1986 r. na zaproszenie OTKO przebywała w Opolu delegacja PZKO z Czeskiego Cieszyna. Celem wizyty było omówienie programu współpracy kulturalnej między PZKO a organizacjami kulturalnymi i towarzystwami regionalnymi

56 AZ PZKO, Opolskie Towarzystwo Kulturalno-Oświatowe, sygn. 1515-530, Życzenia dla PZKO z okazji 40-lecia powołania PZKO z dnia 12 XI 1986 r.

57 Ibidem, Pismo w sprawie przyznania Medalu „W 40-rocznicę powrotu Śląska Opolskiego do Macierzy" z dnia 12 XI 1986 r.

58 T. Soroczyński, Opolskie Towarzystwo Kulturalno-Oświatowe. Kronika ruchu regionalnego kwiecieńwrzesień 1983, „Wczoraj, Dzisiaj, Jutro”, R. XVII (1983), nr 4/65, s. 69.

59 Idem, Opolskie Towarzystwo Kulturalno-Oświatowe. Kronika ruchu regionalnego, „Wczoraj, Dzisiaj, Jutro", R. XVIII (1984), nr 1/66, s. 71.

60 Idem, Opolskie Towarzystwo Kulturalno-Oświatowe (październik-grudzień 1984). Kronika ruchu regionalnego, „Wczoraj, Dzisiaj, Jutro”, R. XIX (1985), nr 1-2/70-71, s. 124

61 Opolskie Towarzystwo Kulturalno-Oświatowe w 1984 roku, „Wczoraj, Dzisiaj, Jutro”, R. XIX (1985), nr 1-2 /70-71, s. 73-74; por. Kronika społeczno-kulturalna wrzesień 1984-sierpień 1985, oprac. T. Soroczyński, „Kalendarz Opolski” 1986, Opole 1986, s. 217. 
na Opolszczyźnie. Przewodniczącego Zarządu Głównego PZKO dr. Stanisława Kondziołkę i sekretarza Zarządu Głównego PZKO Władysława Orszulika przyjął sekretarz Komitetu Wojewódzkiego PZPR Eugeniusz Brudkiewicz. W czasie wizyty goście otrzymali odznaki „Zasłużony Opolszczyźnie”. W trakcie spotkania z kierownictwem OTKO przewodniczący Franciszek Adamiec uhonorował gości odznaką „Zasłużony dla ruchu regionalnego". Natomiast za rozwijanie współpracy z PZKO długoletni działacze OTKO: Eugeniusz Brudkiewicz, Eugeniusz Broczkowski, Stefan Słota, Bernard Waleński oraz pośmiertnie Ryszard Hajduk i Karol Musioł otrzymali złote odznaki „Za zasługi dla PZKO”. Delegacja PZKO w Wydziale Kultury i Sztuki Urzędu Wojewódzkiego spotkała się z dyrektorami wojewódzkich placówek kulturalnych ${ }^{62}$.

Na zaproszenie OTKO we wrześniu 1986 r. gościła na Opolszczyźnie delegacja PZKO: dr hab. Daniel Kadłubiec - przewodniczący Sekcji Folklorystycznej i Jan Szymik - wiceprzewodniczący tej sekcji. Działacze PZKO spotkali się z członkami Komisji Kultury Ludowej OTKO i opolskimi naukowcami, omówili plany współpracy w zakresie upowszechniania kultury, wymiany doświadczeń tych, którzy zawodowo „żyją” sprawami folkloru. Uczestniczyli również w Święcie Plonów w Olszance oraz „Opolskim żniwnioku” w bierkowickim skansenie, a także wzięli udział w uroczystości wręczenia Nagrody Literackiej Markowi Jodłowskiemu. Wiceprzewodniczący OTKO Eugeniusz Brudkiewicz wręczył gościom pamiątkowe medale „W 40 rocznicę powrotu Śląska Opolskiego do Macierzy"63.

Dnia 12 listopada 1986 r. na uroczystym posiedzeniu Zarządu Głównego PZKO zainaugurowano obchody 40. rocznicy działalności związku, który odznaczony został Krzyżem Orderu Odrodzenia Polski. Dekoracji dokonał ambasador PRL w Pradze Andrzej Jedynak. W uroczystości uczestniczyła delegacja z Opola z Krystyną Nessel-Zagórską, zastępcą dyrektora Wydziału Kultury Sztuki Urzędu Wojewódzkiego i prezesem OTKO Franciszkiem Adamcem. Opolanie przekazali pamiątkowy medal wydany przez OTKO z okazji "40-lecia powrotu Opolszczyzny do Macierzy"64. Podczas pobytu delegacji OTKO w Czeskim Cieszynie wręczono Emilowi Sztabli i Bogusławowi Brannemu odznakę OTKO - „Zasłużonemu dla ruchu regionalnego” oraz Henrykowi Szemi przyznaną przez Prezydium Wojewódzkiej Rady Narodowej odznakę „Zasłużonemu Opolszczyźnie”65.

W sierpniu 1987 r. na zaproszenie ZG PZKO w Jabłonkowie na Gorolskim Święcie byli: wicewojewoda opolski - Andrzej Zydek, dyrektor Wydziału Kultury i Sztuki Urzędu Wojewódzkiego - Michał Jaworski, dyrektor Muzeum Wsi Opolskiej -

62 T. Soroczyński, Opolskie Towarzystwo Kulturalno-Oświatowe (styczeń-czerwiec 1986). Kronika ruchu regionalnego, „Wczoraj, Dzisiaj, Jutro”, R. XX (1986), nr 3/86, s. 59; por. Kronika społeczno-kulturalna Ślq̨ska Opolskiego wrzesień 1985-sierpień 1986, oprac. T. Soroczyński, „Kalendarz Opolski” 1987, Opole 1987, s. 217.

63 Idem, Opolskie Towarzystwo Kulturalno-Oświatowe. Kronika ruchu regionalnego lipiec-wrzesień 1986 r., „Wczoraj, Dzisiaj, Jutro”, R. XX (1986), nr 4/86, s. 67.

64 Idem, Opolskie Towarzystwo Kulturalno-Oświatowe. Kronika ruchu regionalnego październik-grudzień 1986 r., „Wczoraj, Dzisiaj, Jutro”, R. XXI (1987), nr 1/87, s. 63

65 Ruch regionalny, „Opole”, R. XVII (1986), nr 10 (194), s. 23 
Krystyna Jesionowska, wiceprezes opolskiego oddziału Polskiego Towarzystwa Ludoznawczego - Teresa Smolińska, dyrektor BWA - Józef Nurkowski oraz plastycy Władysław Początek i Józef Witon. Jabłonkowskie święto wykorzystano do uściślenia planów współpracy ${ }^{6}$. W XV Zjeździe PZKO w Czeskim Cieszynie uczestniczyli: Franciszek Adamiec - prezes i Wacław Suskiewicz - skarbnik OTKO ${ }^{67}$.

W następnym roku na zaproszenie OTKO przebywała na Opolszczyźnie delegacja PZKO w składzie: Roman Suchanek - prezes Zarządu Głównego, Władysław Orszulik - I sekretarz i Jan Cieślar - wiceprezes. Gości zza Olzy przyjął sekretarz KW PZPR - Eugeniusz Brudkiewicz i wicewojewoda opolski - Andrzej Zydek. Podczas spotkania w OTKO Roman Suchanek wręczył Franciszkowi Adamcowi przyznany Towarzystwu medal „Za zasługi”. Uchwalono plan wymiany zespołów artystycznych, twórców i innych grup zawodowych na rok 1989. Goście zapoznali się z zabytkami Brzegu ${ }^{68}$.

W marcu 1989 r. odwiedzili Opole zaolziańscy literaci: Jan Pyszko, Jan Szymik, Gustaw Sajdok, Kazimierz Jaworski, Piotr Przeczek i Urszula Wantuła. W kolejnym miesiącu na zaproszenie ZNP przyjechało czterdziestu nauczycieli ze Szkoły Podstawowej w Jabłonkowie oraz działaczy tamtejszego koła PZKO. Czas spędzili na spotkaniu z opolskimi nauczycielami-twórcami w Niwkach oraz na zwiedzaniu Opola i „Panoramy Racławckiej” we Wrocławiu ${ }^{69}$.

\section{Kontakty przedstawicieli towarzystw regionalnych i kół PZKO}

Niezwykle owocna okazała się współpraca OTKO z Zarządem Głównym PZKO w Czeskim Cieszynie oraz z terenowymi kołami tegoż związku działającymi w poszczególnych powiatach. Kontakty te pozwalały zapoznać naszych rodaków, mieszkających w granicach Republiki Czechosłowackiej, z osiągnięciami województwa opolskiego, ze społeczeństwem, ich tradycjami i problemami ${ }^{70}$.

W wyniku porozumienia zawartego przez Zarząd Główny PZKO i Zarząd OTKO wiosną 1972 r. ustalono następujące współpracujące ze sobą koła i towarzystwa: Koło PZKO w Błędowicach - Towarzystwo Miłośników Ziemi Raciborskiej; Koło PZKO w Czeskim Cieszynie - Towarzystwo Ziemi Kozielskiej; Koło PZKO w Darkowie - Towarzystwo Regionalne Ziemi Strzeleckiej; Koło w Skrzeczoniu - Towarzystwo Miłośników Ziemi Raciborskiej i Wiejski Ośrodek Kultury w Krzanowicach; PZKO w Suchej Górnej - Stowarzyszenie Miłośników Ziemi Oleskiej; Koło PZKO

66 Kronika społeczno-kulturalna Ślq̨ska Opolskiego (wrzesień 1986-sierpień 1987), oprac. T. Soroczyński, „Kalendarz Opolski” 1988, Opole 1988, s. 311.

67 T. Soroczyński, Opolskie Towarzystwo Kulturalno-Oświatowe. Kronika ruchu regionalnego (październik-grudzień 1987 r.), „Wczoraj, Dzisiaj, Jutro”, R. XXII (1988), nr 1-2 (82-83), s. 123.

68 Idem, Opolskie Towarzystwo Kulturalno-Oświatowe. Kronika ruchu regionalnego (lipiec-grudzien 1988 r.), „Wczoraj, Dzisiaj, Jutro”, R. XXIII (1989), nr 1(86), s. 64.

69 Ruch regionalny, „Opole”, R. XX (1989), nr 6 (226), s. 23. 
w Lutyni - Towarzystwo Miłośników Ziemi Głubczyckiej; Koło PZKO w Olbrachcicach - Towarzystwo Miłośników Ziemi Namysłowskiej ${ }^{71}$. Nie wszystkie organizacje podjęły jednak współpracę. W następnym roku delegacja Zarządu Głównego PZKO wzięła udział w II Jesiennym Spotkaniu Opolskich Miłośników Regionu, była to okazja do odnowienia istniejących i nawiązania nowych kontaktów partnerskich. Goście zwiedzili Muzeum Śląska Opolskiego oraz Muzeum Piastów Śląskich w Brzegu i rozmawiali z Zarządem Towarzystwa Miłośników Ziemi Brzeskiej. Delegacja spotkała się z zarządami opolskich towarzystw regionalnych, m.in. Towarzystwa Miłośników Ziemi Namysłowskiej, Towarzystwa Miłośników Ziemi Grodkowskiej i Towarzystwa Przyjaciół Otmuchowa. W spotkaniach tych oprócz działaczy towarzystw uczestniczyli również przedstawiciele miejscowych władz. Efektem pobytu delegacji były plany dalszych kontaktów i współpracy. Nawiązano następujące kontakty: Towarzystwo Miłośników Ziemi Namysłowskiej z Kołem w Olbrachcicach, Towarzystwo Miłośników Ziemi Brzeskiej z Kołem w Bystrzycy oraz ustalono, że Towarzystwo Miłośników Ziemi Grodkowskiej podejmie współpracę z kołem wskazanym przez Zarząd Główny PZKO. Postanowiono również, że OTKO i Instytut Śląski udzielą Zarządowi Głównemu PZKO pomocy w organizacji na terenie Zaolzia spotkania działaczy PZKO o tematyce i formie zbliżonej do II Jesiennego Spotkania Opolskich Miłośników Regionu ${ }^{72}$.

Pod koniec roku ponownie dokonano szczegółowej oceny dotychczasowej współpracy opolskich towarzystw regionalnych z kołami PZKO. Ponieważ nie wszystkie towarzystwa podjęły współdziałanie, w wyniku przeprowadzonych rozmów postanowiono, że współpracę podejmą: Brzeg - Bystrzyca, Grodków zamiast Krzanowic Skrzeczoń, Otmuchów - Karwina I, Kluczbork - Trzyniec VI, Nysa zamiast Głubczyc - Lutynia Górna ${ }^{73}$.

Wysiłek działaczy OTKO zmierzał w kierunku aktywizacji miłośnickich stowarzyszeń i towarzystw przez aktywne uczestnictwo m.in. w konkursach „Bliżej regionu, bliżej kraju”, „Z młodymi i dla młodych”, co zapewniało szerszy kontakt z kołami PZKO w Czechosłowacji ${ }^{74}$.

71 WBP Opole, Protokoły z posiedzeń Prezydium Zarządu 1973, 1974, sygn. 20, Polska Zjednoczona Partia Robotnicza Komitet Wojewódzki w Opolu Wydział Propagandy i Agitacji, s. 1-4; por. Kronika opolskiego ruchu regionalnego (październik 1973-styczeń 1974), „Wczoraj, Dzisiaj, Jutro”, R. VIII (1974), nr 1/26, s. 87.

72 WBP Opole, Protokoły z posiedzeń Prezydium Zarządu 1973, 1974, sygn. 20, Informacja o przebiegu spotkania z delegacją Polskiego Związku Kulturalno-Oświatowego z Czechosłowacji, s. 1-3; por. Opolska Kronika Kulturalna (kwiecień-październik 1973 roku), oprac. B. Waleński, „Wczoraj, Dzisiaj, Jutro”, R. VII (1973), nr 3-4/24-25, s. 114

73 WBP Opole, Protokoły z posiedzeń Prezydium Zarządu 1973, 1974, sygn. 20, Polska Zjednoczona Partia Robotnicza Komitet Wojewódzki w Opolu Wydział Propagandy i Agitacji, s. 1-4; por. Kronika opolskiego ruchu regionalnego (październik 1973-styczeń 1974), „Wczoraj, Dzisiaj, Jutro”, R. VIII (1974), nr 1/26 s. 87.

74 T. Soroczyński, Opolskie Towarzystwo Kulturalno-Oświatowe. Kronika ruchu regionalnego, „Wczoraj Dzisiaj, Jutro", R. XI (1978), nr 2/43, s. 78-79. 


\section{Towarzystwo Ziemi Kozielskiej (TZK) - Koło PZKO w Czeskim Cieszynie}

Dobrze kształtowała się współpraca TZK z Kołem Miejskim PZKO w Czeskim Cieszynie. Jej początki sięgają 1972 r. Przedstawiciele TZK i działacze PZKO spotykali się kilkakrotnie. W rezultacie przeprowadzonych rozmów zawarto porozumienie, przewidziano m.in. wymianę wydawnictw, wzajemne odwiedziny zespołów artystycznych oraz wspólne spotkania zarządów TZK i PZKO. Efektem tego porozumienia były wyjazdy do Czeskiego Cieszyna zespołu artystycznego Technikum Chemicznego w Sławięcicach, orkiestry z Raszowej ${ }^{75}$ i zespołu estradowego Powiatowego Domu Kultury w Koźlu.

Okazją do spotkania w Czeskim Cieszynie stał się jubileusz 25-lecia istnienia Zespołu Śpiewaczego „Harfa”, znanego z krzewienia polskiej pieśni w Czechosłowacji i poza jej granicami. Galowy występ „Harfy” został zorganizowany w Teatrze Cieszyńskim. Z okazji jubileuszu przedstawiciele TZK wręczyli kierownictwu chóru „Medal 800-lecia Koźla” przyznany zespołowi przez Prezydium Powiatowej Rady Narodowej w Koźlu za jego zasługi w rozwijaniu współpracy regionu czeskocieszyńskiego z kozielskim. Chór ten wystąpił na ziemi kozielskiej kilkakrotnie, m.in. w czasie trwania „Dni Ziemi Kozielskiej”.

W czasie pobytów delegacji z Czeskiego Cieszyna w Polsce starano się zaznajomić gości z Opolszczyzną, organizowano zwiedzanie miast oraz wizyty w różnych instytucjach. W czasie pobytu na ziemi kozielskiej osoby z Czeskiego Cieszyna zwiedziły Technikum Żeglugi Śródlądowej w Koźlu, tamtejszą Powiatową i Miejską Bibliotekę Publiczną, Instytut Ciężkiej Syntezy Organicznej (ICSO) i Zakładowy Dom Kultury „Lech” w Kędzierzynie ${ }^{76}$.

Przez wszystkie lata kontynuowano wymianę wydawnictw TZK i PZKO. W jej ramach TZK otrzymywało z Czeskiego Cieszyna miesięcznik „Zwrot”, pisma młodzieżowe: „Nasza Gazetka”, „Ogniwo”, „Jutrzenka” oraz wybrane publikacje wydawane w języku polskim przez wydawnictwo „Profil”, a wysyłało do Czechosłowacji własne pozycje, które ukazywały się w ramach edytorskiej działalności Towarzystwa ${ }^{77}$.

Realizując porozumienia z Kołem Miejskim PZKO w Czeskim Cieszynie, działacze TZK doprowadzili do wymiany grupy wczasowych między Polakami z Czeskiego Cieszyna a ICSO w Kędzierzynie. W ramach tej wymiany w 1974 r. trzydzieści osób z Czeskiego Cieszyna przebywało na wczasach $\mathrm{w}$ ośrodku zakładowym Instytutu nad Bałtykiem, a trzydzieścioro pracowników ICSO na wypoczynku w Beskidzie Morawskim. Podobna liczba osób uczestniczyła w wymianie turystycznej w 1975 r. dzięki staraniom działaczy TZK z dużych zakładów przemysłowych Kędzierzyna. Współpraca z Kołem PZKO w Czeskim Cieszynie przybliżyła mieszkańcom Koźla i Kędzierzyna problematykę mniejszości polskiej w Czechosłowacji, a działaczom

75 R. Pacułt, Towarzystwo Ziemi Kozielskiej. Kronika OTKO i towarzystw regionalnych (od stycznia do marca 1974), „Wczoraj, Dzisiaj, Jutro”, R. VIII (1974), nr 2/27, s. 89.

76 Idem, Towarzystwo Ziemi Kozielskiej. Kronika OTK-O i towarzystw regionalnych (za okres od kwietnia do czerwca 1974), „Wczoraj, Dzisiaj, Jutro”, R. VIII (1974), nr 3/28, s. 78.

77 Idem, Współpraca Towarzystwa Ziemi Kozielskiej z kołem Polskiego Zwiazku Kulturalno-Oświatowego w Czeskim Cieszynie, „Wczoraj, Dzisiaj, Jutro”, R. VIII (1974), nr 1/26, s. 55-58; por. Kronika opolskiego ruchu regionalnego (październik 1973 - styczeń 1974), „Wczoraj, Dzisiaj, Jutro”, R. VIII (1974), nr 1/26, s. 92. 
TZK ułatwiła przyjęcie niektórych form pracy tamtejszych kół. Współpraca ta prowadziła także do umocnienia więzów i kontaktów Polaków mieszkających w Czechosłowacji z ojczyzną, a polskiej młodzieży z Czeskiego Cieszyna stworzyła okazję bliższego poznania kultury polskiej, nawiązania osobistych kontaktów oraz doskonalenia znajomości języka ojczystego ${ }^{78}$.

\section{Towarzystwo Miłośników Ziemi Grodkowskiej (TMZG) - Koło w Skrzeczoniu} Z korzyścią dla obydwu stron układała się współpraca TMZG z Kołem PZKO w Skrzeczoniu. Początki tych kontaktów sięgają 1973 r. Kilkakrotne wizyty przedstawicieli TMZG i działaczy Koła PZKO w Skrzeczoniu doprowadziły do zawarcia porozumienia, w którym postawiono na działalność kulturalno-oświatową, w tym na wymianę zespołów artystycznych, prelegentów i delegacji.

Odbyło się kilka wspólnych spotkań zarządów ${ }^{79}$. W czasie jednego z nich w $1974 \mathrm{r}$. dwaj członkowie TMZG Józef Kośla i W. Kaczanowski otrzymali dyplomy uznania za całokształt działalności między PZKO w Skrzeczoniu a TMZG ${ }^{80}$. Delegacja Zarządu TMZG wzięła udział w uroczystości z okazji 30-lecia PZKO w Karwinie.

W Grodkowie kilkakrotnie gościł z występami Zespół Muzyczny „Meteor”, m.in. w ramach V Jesieni Muzycznej oraz w Opolu w Teatrze im. Jana Kochanowskiego na podsumowaniu młodzieżowej kampanii „Zbieramy płody jesieni”. W Grodkowie wystąpił również z koncertami chór „Hasło”, a z okazji Dni Kultury zespół teatralny „Świt”.

Z kolei w Czechosłowacji w Skrzeczoniu i Boguminie gościł zespół muzyczny „Forum"\$1 oraz zespół regionalny z Sidziny z góralskim widowiskiem pt. Nie turbuj się gorol. Zespoły grodkowskie wystąpiły w Skrzeczoniu z okazji 30-lecia PRL i Słowackiego Powstania Ludowego ${ }^{82}$, a z okazji 30-lecia PZKO 50-osobowa orkiestra GZWM wzięła udział w pochodzie oraz dała trzy koncerty w kołach PZKO. W Muzycznej Jesieni, organizowanej przez Zarząd Główny PZKO, wzięły udział zespoły muzyczne „Makyo” z Grodkowa i „Rebus” z Opola oraz solistka Daria Pakosz ${ }^{83}$.

78 Idem, Towarzystwo Ziemi Kozielskiej w latach 1972-1975, „Wczoraj, Dzisiaj, Jutro”, R. X (1976), nr 1/34 s. $30-31$.

79 jw, Towarzystwo Miłośników Ziemi Grodkowskiej. Kronika OTKO i towarzystw regionalnych (od stycznia do marca 1974), „Wczoraj, Dzisiaj, Jutro”, R. VIII (1974), nr 2/27, s. 87; por. J. Kośla, Towarzystwo Miłośników Grodkowa. Kronika ruchu regionalnego, „Wczoraj, Dzisiaj, Jutro”, R. XIV (1980), nr 1/50, s. 91; Ruch regionalny, „Opole”, R. XVIII (1987), nr 1 (197), s. 24; E. Hoszowski, Grodków-Skrzeczoń - pożyteczna współpraca, Wczoraj, Dzisiaj, Jutro”, R. XI (1977), nr 4/41, s. 45-46; J. Kośla, Towarzystwo Miłośników Grodkowa. Kronika ruchu regionalnego (październik-grudzień 1987), „Wczoraj, Dzisiaj, Jutro”, R. XXII (1988), nr 1-2/82-83, s. 127-128; idem, Towarzystwo Miłośników Grodkowa. Kronika ruchu regionalnego (styczeń-marzec 1989 r.), „Wczoraj, Dzisiaj, Jutro”, R. XXIII (1989), nr 2-3/87-88, s. 113.

80 J. Kośla, Towarzystwo Miłośników Ziemi Grodkowskiej. Kronika ruchu regionalnego, „Wczoraj, Dzisiaj, Jutro", R. IX (1975), nr 1/30, s. 114-115.

81 E. Hoszowski, Towarzystwo Miłośników Ziemi Grodkowskiej. Kronika ruchu regionalnego, „Wczoraj Dzisiaj, Jutro", R. IX (1975), nr 2/31, s. 68.

82 Towarzystwo Miłośników Ziemi Grodkowskiej. Kronika ruchu regionalnego, oprac. J. Kośla, „Wczoraj, Dzisiaj, Jutro", R. VIII (1974), nr 4/29, s. 65.

83 J. Kośla, Towarzystwo Miłośników Grodkowa. Kronika ruchu regionalnego, „Wczoraj, Dzisiaj, Jutro”, R. XIV (1980), nr 1/50, s. 91. 
Ponadto młodzieżowy klub „Forum” utrzymywał kontakty z młodzieżowym klubem w Skrzeczoniu. Wymiana ta przyniosła wiele korzyści, gdyż grodkowianie poznali osiągnięcia, kulturę i obyczaje mniejszości polskiej na Zaolziu.

Corocznie organizowane były rajdy rowerowe połączone $\mathrm{z}$ organizacją wspólnych imprez i zawodów sportowych oraz wycieczki po Polsce. W ramach współpracy zorganizowano dla 50-osobowej grupy przedstawicieli PZKO wycieczkę. Goście zwiedzili Grodków, Otmuchów i Kotlinę Kłodzką. Z kolei grupa pięćdziesięciu członków GTKO przebywała w Ośrodku Zarządu Głównego PZKO w Kosarzyskach ${ }^{84}$.

\section{Stowarzyszenie Miłośników Ziemi Oleskiej (SMZO) - PZKO w Suchej Górnej}

Jednym z poważniejszych działów pracy SMZO była w współpraca z Polakami w Czechosłowacji. Kontakty z Kołem PZKO w Suchej Górnej zostały nawiązane 1971 r. Wzorem innych towarzystw $\mathrm{w}$ wyniku porozumienia odbywały się wspólne posiedzenia zarządów ${ }^{85}$. Delegacje obydwóch instytucji odwiedzały się m.in. podczas uroczystości związanych z jubileuszem organizacji czy też świętami miast. Goście z Suchej Górnej uczestniczyli m.in. w Dniach Olesna, natomiast zarząd SMZO przebywał na uroczystościach jubileuszowych z okazji 25-lecia istnienia Koła.

Współpraca dotyczyła przede wszystkim działalności kulturalno-oświatowych, a polegała na przekazywaniu wzajemnych doświadczeń i realizacji wspólnych imprez. Nauczyciele - działacze SMZO wzięli udział w konferencji metodycznej polskich i czeskich szkół ogniska metodycznego Hawierzów - Czeski Cieszyn - Sucha Górna, na której to konferencji zaprezentowali elementy systemu dydaktyczno-wychowawczego wdrażanego w oleskich szkołach. W marcu 1974 r. przebywała na ziemi oleskiej 45-osobowa grupa nauczycieli i działaczy PZKO z Suchej Górnej. Goście mieli okazję zapoznać się z dorobkiem powiatu oleskiego, jego historią, odwiedzili oleskie szkoły oraz miejsca pamięci narodowej, zabytki i obiekty kulturalne. Zwiedzili ponadto Opole, Górę św. Anny i Muzeum Czynu Powstańczego w Leśnicy. Z kolei polscy nauczyciele, członkowie SMZO, gościli w polskiej i czeskiej szkole w Suchej Górnej, w Ostrawie, Trzyńcu oraz w skansenie w Rożnowie.

Na ziemi oleskiej występowały również zespoły artystyczne Koła PZKO z Suchej Górnej. Wśród nich były zespoły wokalne „Melodia”, „Gama”, „Robinsonki”, taneczny i recytatorski.

Kontakty osobiste dały społeczności oleskiej doskonałą okazję do zapoznania się z życiem mniejszości polskiej w Czechosłowacji. W ramach współpracy wymieniano wydawnictwa, popularyzowano wiedzę o regionach, zapoznawano się z działalnością organizacji. Podjęta współpraca między SMZO a PZKO w Suchej Górnej doprowadziła do nawiązania współpracy między szkołami i bibliotekami, jak również do indywidualnych kontaktów, co pozwoliło na wzajemne zapoznanie się z warunkami życia i pracy obydwu środowisk ${ }^{86}$. 


\title{
Towarzystwo Miłośników Ziemi Namysłowskiej (TMZN) - Koło PZKO w Olbrachcicach
}

Kolejną instytucją utrzymującą kontakty z Polakami na Zaolziu było TMZN, które od wielu lat współpracowało z Kołem PZKO w Olbrachcicach. Po nawiązaniu współpracy między towarzystwem a kołem i zapoznaniu się z działalnością obydwu instytucji przygotowano plan kontaktów na następne lata. Obejmował on wspólne posiedzenia zarządów ${ }^{87}$, uczestniczenie delegacji w jubileuszach organizacji, wymianę wydawnictw i zespołów artystycznych, wycieczki krajoznawcze.

W uroczystym jubileuszu 30-lecia działalności PZKO w Czechosłowacji wzięło udział Namysłowskie Towarzystwo Społeczno-Kulturalne (NTSK) ${ }^{88}$. Delegacja NTSK wraz z grupą harcerzy, reprezentanci Domu Kultury i Kombinatu PGR wraz z orkiestrą uczestniczyli w obchodach 150 . rocznicy otwarcia szkoły polskiej w Olbrachcicach. Namysłowscy harcerze przebywający na obozie w Skoczowie trzykrotnie odwiedzili tamtejszą młodzież. Po czym z rewizytą przyjechała do Namysłowa młodzież z Olbrachcic. Zwiedzili oni Górę św. Anny, Turawę, Oświęcim i Wrocław. W przyjęciu gości pomogli Towarzystwu dyrektorzy Kombinatu PGR i Zespołu Szkół Mechanicznych $^{89}$

Ponowną okazją do spotkania był jubileusz 25-lecia TMZN. W uroczystościach wzięła udział delegacja Koła PZKO z Olbrachcic w Czechosłowacji ${ }^{90}$.

\begin{abstract}
Zakładowe Koło Kultury przy ZBP „Frotex” (ZKK) - Koło w Datyniach Dolnych Owocna była współpraca Zakładowego Koła Kultury ZBP „Frotex” z Prudnika z Kołem PZKO w CSRS w Datyniach Dolnych. W czasie pierwszej wizyty w Prudniku, w listopadzie 1977 r., delegacja Koła PZKO zwiedziła miasto i zakłady, uczestniczyła w uroczystej wieczornicy z okazji 60. rocznicy rewolucji październikowej, zapoznała się z działalnością ZKK i możliwościami wzajemnych kontaktów ${ }^{91}$.

Współpraca kół polegała na wymianie wydawnictw, zespołów artystycznych, organizowaniu kolonii i obozów dla dzieci działaczy PZKO, wspólnym przygotowywaniu imprez kulturalnych. W celu sprawnej realizacji tych założeń odbywały się wspólne posiedzenia zarządów kół. Wzajemne wizyty pozwalały na lepsze poznanie środowiska i działalności obydwu organizacji.
\end{abstract}

87 Zob. K. Kuliński, Towarzystwo Miłośników Ziemi Namysłowskiej. Kronika OTK-O i towarzystw regionalnych (za okres od kwietnia do czerwca 1974), „Wczoraj, Dzisiaj, Jutro”, R. VIII (1974), nr 3/28, s. 80; Kronika społeczno-kulturalna (wrzesień 1976-sierpień 1977), oprac. T. Soroczyński, „Kalendarz Opolski” 1978, Opole 1978, s. 226.

88 K. Kuliński, Namysłowskie Towarzystwo Społeczno-Kulturalne. Kronika ruchu regionalnego, „Wczoraj, Dzisiaj, Jutro", R. XI (1978), nr 1/78, s. 75.

89 Idem, Namysłowskie Towarzystwo Społeczno-Kulturalne. Kronika ruchu regionalnego, „Wczoraj, Dzisiaj, Jutro", R. XI (1978), nr 4/45, s. 81.

90 J. Kawecka, Towarzystwo Miłośników Ziemi Namysłowskiej. Kronika ruchu regionalnego, „Wczoraj, Dzisiaj, Jutro", R. XVIII (1984), nr 3/68, s. 79.

91 M. Karp, Zakładowe Koło Kultury ZPB „Frotex” w Prudniku. Kronika ruchu regionalnego, „Wczoraj, Dzisiaj, Jutro", R. XI (1978), nr 1/78, s. 80 
Delegacje „Frotexu” bywały z wizytami w Czechosłowacji. Członkowie ZKK zwiedzili m.in. Czeski Cieszyn, redakcję „Zwrotu”, Hawierzów, Żywocicie, miejsce katastrofy samolotu Żwirki i Wigury w okolicach Cierlicka, Datynie, Bukowiec, Ostrawę. Wzięli też udział w uroczystym „Wieczorze Przyjaźni”, centralnej imprezie PZKO dla uczczenia 30. rocznicy wydarzeń lutowych w Czechosłowacji ${ }^{92}$. Ponadto delegacja ZKK uczestniczyła w „Gorolskim Święcie”, odwiedziła nowy dom PZKO w Bukowcu i zwiedziła Ostrawę ${ }^{93}$.

Z kolei w Prudniku przebywała 50-osobowa grupa reprezentująca amatorski ruch artystyczny PZKO w Czechosłowacji. W Koncercie Przyjaźni „Hej, koło Cieszyna" wystąpił chór mieszany, instrumentaliści, recytatorzy, zespół taneczny i zespół wokalny „Melodia” z solistką Jadwigą Niemiec. Koncert był okazją do spotkania wszystkich członków ZKK, podsumowania pracy i wręczenia po raz pierwszy fundowanej przez ZKK „Nagrody Roku” za upowszechnianie kultury w środowisku robotniczym $^{94}$. Goście zwiedzili m.in. Opole, Nysę, Paczków, Otmuchów, Muzeum Wsi Opolskiej w Bierkowicach i Muzeum Czynu Powstańczego w Leśnicy oraz prudnicki „Frotex”. Spotkali się na Górze św. Anny z powstańcami śląskimi, a w opolskiej „Musiałówce” z działaczami regionalnymi Opolszczyzny ${ }^{95}$.

W jubileuszu 30-lecia istnienia Koła Miejscowego PZKO w Hawierzowie-Datyniach Dolnych w Czechosłowacji wzięła udział delegacja ZKK. Uroczystościom towarzyszyła wystawa prezentująca dorobek koła i dwuletnią historię współpracy Datynie - Prudnik ${ }^{96}$.

Wszystko to doprowadziło do powstania trwałych, usankcjonowanych na piśmie więzów przyjaźni pomiędzy towarzystwami regionalnymi Opolszczyzny a kołami PZKO w Czechosłowacji. O potrzebie kontynuowania tej dobrej tradycji, a także poszerzenia współpracy mówił podczas wizyty Stanisław Kondziołka - przewodniczący PZKO z dyrektorami Wydziału Kultury i Sztuki Urzędu Wojewódzkiego, Teatru im. J. Kochanowskiego, Wojewódzkiego Domu Kultury, WBP i BWA w Opolu97.

92 Idem, Zakładowe Koło Kultury ZPB „Frotex” w Prudniku. Kronika ruchu regionalnego, „Wczoraj, Dzisiaj, Jutro", R. XI (1978), nr 2/43, s. 90-91.

93 Idem, Zakładowe Koło Kultury ZPB „Frotex”. Kronika ruchu regionalnego „Wczoraj, Dzisiaj, Jutro”, R. XI (1978), nr 4/45, s. 83.

94 Idem, Zakładowe Koło Kultury ZPB „Frotex” w Prudniku. Kronika ruchu regionalnego, „Wczoraj, Dzisiaj, Jutro", R. XI (1978), nr 3/44, s. 106.

95 Idem, Zakładowe Koło Kultury ZPB „Frotex” w Prudniku. Kronika ruchu regionalnego, „Wczoraj, Dzisiaj, Jutro", R. XII (1979), nr 2-3/47-48, s. 149-150.

96 Idem, Zakładowe Koło Kultury ZPB „Frotex” w Prudniku. Kronika ruchu regionalnego, „Wczoraj, Dzisiaj, Jutro", R. XIII (1979), nr 4/79, s. 105.

97 Polacy spoza Polski, „Opole”, R. XIV (1983), nr 12 (160), s. 26. 


\section{Współpraca w dziedzinie kultury}

\section{Prasa i literatura}

Kontakty dziennikarzy i literatów z Zaolzia i Opolszczyzny były bardzo częste. Zapraszani oni byli na różnego rodzaju uroczystości, jubileusze czy imprezy prasowe w Opolu. Zwyczajem stało się goszczenie polskich dziennikarzy zrzeszonych w PZKO na święcie „Trybuny Odrzańskiej”, w którym uczestniczyli m.in. Bronisław Bielan ze „Zwrotu”, Kazimierz Kaszper z „Głosu Ludu”. Podobne kontakty nawiązywali literaci z SLA, którzy odwiedzali miasto podczas np. Opolskich Dni Literatury ${ }^{98}$. Częstymi gośćmi na Opolszczyźnie byli Wilhelm Przeczek, Władysław Sikora, Kazimierz Kaszper, Jan Pyszko, Wiesław Adam Berger, Karol Suszka. Literaci przyjmowani byli przez przewodniczącego OTKO - Ryszarda Hajduka, spotykali się z przedstawicielami opolskiego środowiska literackiego, członkami Komisji Współpracy z Zagranica, rozmawiali z młodzieżą zrzeszoną w Kole Młodych przy opolskim oddziale ZLP, brali udział w seminariach literackich zorganizowanych przez ZNP ${ }^{99}$. Uczestniczyli również w wieczorach autorskich w Klubie Związków Twórczych w ramach „Czwartku Literackiego"100 oraz w towarzystwach regionalnych Opolszczyzny, gdzie mówili o twórczości kolegów i o swojej własnej, a także prezentowali utwory literackie ${ }^{101}$.

Redaktorzy „Zwrotu” przyjeżdżali na Opolszczyznę również w celu zebrania materiałów dotyczących m.in. pracy z młodzieżą oraz działalności towarzystw regionalnych w małych środowiskach ${ }^{102}$.

Z kolei opolscy dziennikarze brali udział w uroczystościach na Zaolziu, okazją do tego był m.in. jubileusz 30-lecia istnienia miesięcznika „Zwrot”. W uroczystościach wzięła udział delegacja OTKO w składzie: redaktor Edward Pochroń - przewodniczący Komisji Wydawniczej oraz sekretarz towarzystwa - Tadeusz Soroczyński ${ }^{103}$.

Współpraca ta dotyczyła także publikowania artykułów ukazujących się na Opolszczyźnie i na Zaolziu, które informowały o ważnych uroczystościach, wystawach, wieczorach poetyckich, życiu teatralnym, przedstawiały recenzje książek i opisywały działalność instytucji kulturalnych. Na Opolszczyźnie tematyką zaolziańską

98 WBP Opole, Protokoły z posiedzeń Prezydium Zarządu OTKO i Zarządu OTKO 1979 r., sygn. 95, Kontakty Opolskiego Towarzystwa Kulturalno-Oświatowego z Polakami z Polskiego Związku Kulturalno-Oświatowego w Czechosłowacji (1978), s. 4; por. W placówkach kultury, „Opole”, R. XIX (1988), nr 4 (212), s. 23

99 T. Soroczyński, Opolskie Towarzystwo Kulturalno-Oświatowe. Kronika ruchu regionalnego, „Wczoraj, Dzisiaj, Jutro”, R. XIV (1980), nr 2-3/51-52, s. 64; idem, Opolskie Towarzystwo Kulturalno-Oświatowe (lipiec-wrzesień 1985). Kronika ruchu regionalnego, „Wczoraj, Dzisiaj, Jutro”, R. XIX (1985), nr 4/73, s. 51; Życie Literackie, „Opole”, R. XVII (1986), nr 8 (192), s. 23.

100 Kronika społeczno-kulturalna Ślqska Opolskiego (wrzesień 1987-sierpień 1988), oprac. T. Soroczyński, „Kalendarz Opolski” 1989, Opole 1989, s. 245.

101 M. Karp, Zakładowe Koło Kultury ZPB „Frotex” w Prudniku. Kronika ruchu regionalnego styczeń-marzec 1980, „Wczoraj, Dzisiaj, Jutro”, R. XIV (1980), nr 2-3/51-52, s. 69-70.

102 Działalność Opolskiego Towarzystwa Kulturalno-Oświatowego w 1988 roku, „Wczoraj, Dzisiaj, Jutro”, R. XXIII (1989), nr 2-3 (87-88), s. 81.

103 Materiały na IV Zjazd OTKO, Opole 1983, s. 43-44; por. T. Soroczyński, Opolskie Towarzystwo Kulturalno-Oświatowe. Kronika ruchu regionalnego, „Wczoraj, Dzisiaj, Jutro”, R. XIV (1980), nr 1/50, s. 87. 
zajmowały się: miesięcznik „Opole”, kwartalnik „Wczoraj, Dzisiaj, Jutro”, rocznik „Kalendarz Opolski”, okazjonalnie artykuły bądź wiersze zamieszane były także w „Trybunie Odrzańskiej". Na Zaolziu najwięcej informacji o Opolszczyźnie ukazywało się w miesięczniku „Zwrot”, pojawiały się również wzmianki w „Głosie Ludu”.

W miesięczniku „Opole” było kilka stałych rubryk informujących społeczność opolską o życiu mniejszości polskiej na Zaolziu. W rubryce „Perspektywa Południe” pisano m.in. o działalności Polaków mieszkających w Czechosłowacji, przedstawiano historię pism wychodzących na czesko-polskim pograniczu - „Zwrotu” i „Głosu Ludu". Na łamach tego pierwszego były zamieszczane artykuły o współpracy polsko-czesko-słowackiej, o rozwoju polskiej kultury i sztuki, recenzje nowości wydawniczych. W „Zwrocie” prezentowano również poezję polską oraz twórczość miejscowych poetów. Redakcja miesięcznika skupiła wokół siebie grupę twórców, dzięki ich wieloletniej współpracy ukazała się publikacja Podanie ręki, wydana z okazji 20-lecia „Zwrotu”. „Głos Ludu” z kolei przytaczał bieżące informacje krajowe i zagraniczne. Prócz doniesień o życiu Polaków mieszkających w tym regionie, zamieszczane były tam też wiadomości o wydarzeniach w Polsce ${ }^{104}$.

W cyklu „Perspektywa Południa” przedstawiani byli również polscy pisarze tworzący na Zaolziu. Jednego z nich, Wiesława Adama Bergera, zaprezentował Bogusław S. Kunda ${ }^{105}$. Na łamach „Opola” mogliśmy przeczytać również fragmenty powieści pisarzy czy też wiersze Władysława Sikory ${ }^{106}$, Wilhelma Przeczka ${ }^{107}$, Kazimierza Kaszpera ${ }^{108}$.

W dziale „Recenzje” w miesięczniku „Opole” omawiane były m.in. najnowsze wydawnictwa autorów zaolziańskich. Wśród nich można było zaznajomić się m.in. z twórczością Józefa Ondrusza, który zaprezentował czytelnikom Prozę ludowq górników karwińskich ${ }^{109}$. Kolejną omawianą publikacją była antologia Światłocienie,

104 Perspektywa Południe, „Opole”, R. I (1970), nr 5, s. 23.

105 B.S. Kunda, Pisarz z Ostrawy, „Opole”, R. III (1972), nr 2 (22), s. 15.

106 Zob. W. Sikora, Odległy dotyk, Za górami, Wszystko inne, „Opole”, R. III (1972), nr 2 (22), s. 18; idem Miasto po deszczach, Koszarzyska, „Opole”, R. XI (1980), nr 8 (124), s. 15; idem, Las osobny, „Opole”, R. XVIII (1987), nr 6 (202), s. 14

107 Zob. W. Przeczek, Lawina wypielęgnowanych wyrazów, „Opole”, R. III (1972), nr 2 (22), s. 18; idem, Oto jest nakaz, „Opole”, R. IV (1973), nr 3 (35), s. 18; idem, Po ciemnych nocach ciemne sprawy idq; Grajdołki, „Opole”, R. VI (1975), nr 1 (57), s. 18; idem, Dzieworyt horyzontu jak widokówka z Nowiny, „Opole”, R. VIII (1977), nr 4 (84), s. 18; idem, Po korytarzach: z owcami, wilkami, Zaczepny punkt wyjścia, Zamówione rozbieranie, Karczowo bez słowa, „Opole”, R. X (1979), nr 4 (108), s. 18; idem, Kosmiczna koronkarka, Spowiedź w blasku, Promień, „Opole”, R. XI (1980), nr 8 (124), s. 14; idem, Niepokój, Marsz w Czeskim Cieszynie, Ucieszne miasteczka, „Opole”, R. XII (1981), nr 10 (138), s. 14; idem, Opole Opole, Zaduszki, Robaczek świętojański, Zielone święta, „Opole”, R. XV (1984), nr 10 (170), s. 14-15; idem, Spodnie na szelkach, Astry, Czysta tablica, „Opole”, R. XVI (1985), nr 8 (180), s. 15; idem, Dworzec katowicki, „Opole”, R. XVII (1986), nr 7 (191), s. 15; idem, Kubeczek, „Opole”, R. XVIII (1987), nr 2 (198), s. 14.

108 Zob. K. Kaszper, Antybajka, „Opole”, R. VI (1975), nr 9 (65), s. 18; idem, Liryk - nadzieja, List pożegnalny, Podszepty, „Opole”, R. XVII (1986), nr 7 (191), s. 14.

109 J. Hajduk, Nowa antologia tekstów górniczych, „Opole”, R. VI (1975), nr 4 (60), s. 28-29. 
w której trzej autorzy: Kazimierz Kaszper, Tadeusz Wantuła i Jan D. Zolich zamieścili swoje wiersze ${ }^{110}$.

W dziale „Przegląd Kulturalny” w miesięczniku „Opole” zamieszane były artykuły m.in. o 25-leciu Teatru Lalek „Bajka”, założonego w 1947 r. nad Olzą przez Ferdynanda Króla. Z okazji ćwierćwiecza istnienia tego teatru została też wydana publikacja $^{111}$.

Rubryka „Z Ostrawy i Cieszyna” w „Opolu” omawiała ciekawsze wydarzenia z Zaolzia. Tutaj również mogliśmy przeczytać o „Głosie Ludu”, który autor tekstu porównywał do „Nowin” - opolskich lub raciborskich: „ta sama nieuchwytna specyfika w układzie graficznym, wynikająca choćby z zachłannego wykorzystania każdego skrawka na polskie słowo"112. Z tej rubryki dowiadywaliśmy się także o przekazaniu przez Ministerstwo Oświaty i Wychowania Polskiej Rzeczypospolitej Ludowej szkołom polskim w Czechosłowacji materiałów do nauczania. Dar ten miał niewymierną wartość ${ }^{113}$. Dział ten informował również o jubileuszach szkół114, o spotkaniach polonistów i dziennikarzy "Głosu Ludu”, którzy dyskutowali na temat kształcenia kadry pedagogicznej dla szkół polskich ${ }^{115}$, czy też o sukcesach zespołów artystycznych: „Promyka”, „Górnika”, „Przyjaźni”, „Olzy”116, działalności amatorskiego ruchu teatralnego, który odegrał ważną rolę w kształtowaniu oblicza narodowego, społecznego i kulturalnego mieszkańców Zaolzia ${ }^{117}$. Na łamy „Zwrotu” i „Głosy Ludu” wracała od czasu do czasu tematyka języka Polaków w Czechosłowacji, polszczyzny coraz uboższej, bo „zasobniejszej” w zwroty obcojęzyczne ${ }^{118 ;}$; „Język stanowi naród, a raczej stanowi oddzielność narodu od narodu. Z zatarciem tylko ojczystej mowy ginie i imię ojczyzny. Żaden lud nie ma więcej potrzeby czuwania nad tym zagrożeniem jak my Polacy" - ten fragment wypowiedzi Juliana Ursyna Niemcewicza z wieku XIX Tadeusz Wantuła przywołał w świątecznym wydaniu „Zwrotu” z 1979 r.119

110 B. Żurakowski, Młodzi poeci cieszyńscy, „Opole”, R. VIII (1977), nr 5 (85), s. 26-28.

111 (m. j.), 25 lat „Bajki”, „Opole”, R. IV (1973), nr 11 (43), s. 33.

112 Z Ostrawy i Cieszyna, „Opole”, R. IX (1978), nr 3 (95), s. 30.

113 Z Ostrawy i Cieszyna, „Opole”, R. IX (1978), nr 6 (98), s. 29.

114 Z Ostrawy i Cieszyna, „Opole”, R. IX (1978), nr 8 (100), s. 31.

115 Z Ostrawy i Cieszyna, „Opole”, R. IX (1978), nr 9 (101), s. 29.

116 Z Ostrawy i Cieszyna, „Opole”, R. X (1979), nr 5 (109), s. 32.

117 Z Ostrawy i Cieszyna, „Opole”, R. XI (1980), nr 12 (128), s. 24-25.

118 Z Ostrawy i Cieszyna, „Opole”, R. X (1979), nr 9 (113), s. 29.

119 Z Ostrawy i Cieszyna, „Opole”, R. X (1979), nr 2 (106), s. 29. 
W rubryce „List z Cieszyna” Kazimierz Kaszper opisywał codzienne zmagania Polaków z Zaolzia związane z zachowaniem i propagowaniem swego dorobku kulturalnego. Poczucie wspólnoty i własnej wartości - podkreślał Kaszper - realizuje się na Zaolziu nie tylko poprzez świetną organizację amatorskiego ruchu artystycznego oraz osiągnięcia twórcze, lecz także poprzez solidną pracę zawodową i nienaganną postawę obywatelską ${ }^{120}$. Pisał też Kaszper o tożsamości Zaolziaków, według niego: „Cieszyniacy bardziej podkreślają swoją regionalną odrębność, a Zaolziacy - łączność z Polską, zwłaszcza z bieżącą kulturą twórczą"121. W kolejnym tekście Kazimierz Kaszper stwierdził, że „po czechosłowackiej stroni Olzy żyje jeszcze kilkadziesiąt tysięcy Polaków, którzy poza wszystkim nauczyli się dostrzegać wartości zarówno polskiej, jak i czeskiej kultury. I korzystać z nich"122. W późniejszym artykule Kazimierz Kaszper pisał, że dla zaolziańskich twórców ważną sprawą jest kontakt z żywą, współczesną polszczyzną. Tym ludziom należałoby stworzyć szansę częstszego i dłuższego bytowania w Polsce. Głód poznania, głód uczestnictwa oto znamiona klimatu, jaki zastał on wśród literatów i muzyków ${ }^{123}$.

Festiwale i mosty graniczne na Olzie w Cieszynie zostały również przez Kazimierza Kaszpera opisane. W lipcu 1986 r. Cieszyn funkcjonował jako jedno z sześciu miast warsztatowych VII Światowego Festiwalu Polonijnych Zespołów Folklorystycznych w Rzeszowie. W środowiskach polonijnych kultura ludowa stanowi jeden ze składników narodowej identyfikacji. Pielęgnowanie jej, owo nieustanne „ocalanie od zapomnienia" dawnych strojów, chat, gawęd, tańców i pieśni przekształca się często w jedyną manifestację przynależności polonijnego środowiska do kultury polskiej ${ }^{124}$.

Zamieszczone były też w „Opolu” i inne publikacje, m.in. recenzje z wystaw artystów z PZKO, np. Franciszka Bałona i Tadeusza Bergera w Opolu ${ }^{125}$.

Z okazji jubileuszu 40-lecia PZKO „Opole” przypomniało historię i działalność PZKO ${ }^{126}$. Redaktor naczelny Jan Goczoł zapowiedział również prezentację utworów mało znanych autorów zza Olzy. Obok „klasyków” współczesnego pisarstwa polskiego na tym terenie, Henryka Jasiczka, Janusza Gaudyma, Wilhelma Przeczka, Władysława Sikory, Jana Rusnoka czy Kazimierza Kaszpera, „żyją tam i piszą jeszcze liczni inni"127. Pojawiły się zatem wiersze młodych autorów: Jacka Sikory ${ }^{128}$,

120 K. Kaszper, Regionalizm raz jeszcze, „Opole”, R. XVII (1986), nr 1 (185), s. 25-26.

121 Idem, Dwa oblicza regionu, „Opole”, R. XVII (1986), nr 3 (187), s. 23-24.

122 Idem, Granica zmienia optykę, „Opole”, R. XVII (1986), nr 4 (188), s. 24-25.

123 Idem, Głód uczestnictwa, „Opole”, R. XVII (1986), nr 6 (190), s. 26.

124 Idem, Mosty, festiwale, „Opole”, R. XVII (1986), nr 10 (194), s. 26,

125 D. Nowicka, Przedstawiamy Franciszka Bałona współautora wystawy „Grafika-fotografika”, „Opole”, R. VIII (1977), nr 10 (90), s. 31.

126 K. Kaszper, Casus: mazut, „Opole”, R. XVIII (1987), nr 4 (200), s. 25.

127 J. Goczoł, Znad Olzy, „Opole”, R. XVIII (1987), nr 6 (202), s. 3.

128 J. Sikora, Demilitaryzacja, Las osobny, „Opole”, R. XVIII (1987), nr 6 (202), s. 14. 
Lucyny Przeczek ${ }^{129}$ i Renaty Putzlacher ${ }^{130}$, jak również Opowiadania znad Olzy, w których swoją twórczość zaprezentował Wiesław A. Berger ${ }^{131}$.

W „Opolu” drukowane były też opowiadania autorstwa Wilhelma Przeczka Wielki szlem rabina ${ }^{132}$ i Garb krawca Gawlika ${ }^{133}$ oraz artykuł jego autorstwa dotyczący twórczości poetyckiej Jana Pilařa ${ }^{134}$. Autor poświęcił rok na tłumaczenie poezji tego poety, konsultując je z samym zainteresowanym.

W „Opolu” ukazała się seria artykułów na temat Małego leksykonu nadolziańskiego. Autor i zarazem pomysłodawca projektu Zenon Jasiński stwierdził, że wśród licznych słowników i encyklopedii brakuje opracowania na temat mniejszości polskiej na Zaolziu. Celem leksykonu było dostarczenie informacji o ludziach i sprawach Zaolziańskiego Śląska. W opracowaniu zostały wyodrębnione hasła: biograficzne, problemowe, dotyczące organizacji i instytucji, polskiej prasy, związane z dziejami miejscowości, gdzie Polacy stanowili niegdyś znaczny procent mieszkańców $^{135}$. Na łamach 36 numerów „Opola” pojawiło się 270 haseł, 60 ilustracji, które miały - jak napisał Z. Jasiński w ostatniej drukowanej części Małego leksykonu nadolziańskiego - wykazać zasadność stwierdzenia, że „Śląsk Cieszyński stanowi swoisty fenomen kulturowy".

Tematyka zaolziańska znajdowała odbicie $\mathrm{w}$ artykułach zamieszczonych w periodyku „Wczoraj, Dzisiaj, Jutro” („WDJ”), wydawanym przez OTKO. Po nawiązaniu bezpośrednich kontaktów pomiędzy OTKO a PZKO na łamach „WDJ” Kazimierz Santarius przedstawił czytelnikom historię i funkcjonowanie PZKO, opisując działalność

129 L. Przeczek, Kartografia, Las osobny, „Opole”, R. XVIII (1987), nr 6 (202), s. 14.

130 Zob. R. Putzlacher, Nocny spacer, Las osobny, „Opole”, R. XVIII (1987), nr 6 (202), s. 15; idem, Strach, Los, Nowoczesna sielanka, Tajemnica kulis, Starość, „Opole”, R. XIX (1988), nr 8 (216), s. 14-15.

131 W.A. Berger, Ja Adam, Las osobny, „Opole”, R. XVIII (1987), nr 6 (202), s. 14-16.

132 W. Przeczek, Wielki szlem rabina, „Opole”, R. XIX (1988), nr 1 (209), s. 14-16.

133 Idem, Garb krawca Gawlika, „Opole”, R. XX (1989), nr 5 (225), s. 14-16.

134 Idem, Polonica w poezji Jana Pilařa, „Opole”, R. XIX (1988), nr 5 (213), s. 8-10, 18.

135 Zob. Z. Jasiński, Mały leksykon nadolziański, „Opole”, R. XVII (1986), nr 7 (191), s. 17-18; „Opole”, R. XVII (1986), nr 8 (192), s. 17-18; „Opole”, R. XVII (1986), nr 9 (193), s. 17; „Opole”, R. XVII (1986) nr 10 (194), s. 17-18; „Opole”, R. XVII (1986), nr 11 (195), s. 17-18; „Opole”, R. XVII (1986), nr 12 (196), s. 17; „Opole”, R. XVIII (1987), nr 1 (197), s. 17-18; „Opole”, R. XVIII (1987), nr 2 (198), s. 17; „Opole”, R. XVIII (1987), nr 3 (199), s. 17-18; „Opole”, R. XVIII (1987), nr 4 (200), s. 17-18; „Opole”, R. XVIII (1987), nr 5 (201), s. 17-18; „Opole”, R. XVIII (1987), nr 6 (202), s. 17-18; „Opole”, R. XVIII (1987), nr 7 (203), s. 17; „Opole”, R. XVIII (1987), nr 8 (204), s. 17-18; „Opole”, R. XVIII (1987), nr 9 (205), s. 17-18; „Opole”, R. XVIII (1987), nr 10 (206), s. 17-18; „Opole”, R. XVIII (1987), nr 11 (207), s. 17-18; „Opole”, R. XVIII (1987), nr 12 (208), s. 17; „Opole”, R. XIX (1988), nr 1 (209), s. 17-18; „Opole”, R. XIX (1988), nr 2 (210), s. 17-18; „Opole”, R. XIX (1988), nr 3 (211), s. 17-18; „Opole”, R. XIX (1988), nr 4 (212), s. 17-18; „Opole”, R. XIX (1988), nr 5 (213), s. 17-18; „Opole”, R. XIX (1988), nr 6 (214), s. 17-18; „Opole”, R. XIX (1988), nr 7 (215), s. 17-18; „Opole”, R. XIX (1988), nr 8 (216), s. 18; „Opole”, R. XIX (1988), nr 9 (217), s. 17-18; „Opole”, R. XIX (1988), nr 10 (218), s. 17-18; „Opole”, R. XIX (1988), nr 11 (219), s. 17-18; „Opole”, R. XIX (1988), nr 12 (220), s. 17-18; „Opole”, R. XX (1989), nr 1 (221), s. 17-18; „Opole”, R. XX (1989), nr 2 (222), s. 17; „Opole”, R. XX (1989), nr 3 (223), s. 17; „Opole”, R. XX (1989), nr 4 (224), s. 17-18; „Opole”, R. XX (1989), nr 5 (225), s. 17-18; (Suplement cz. 1), „Opole”, R. XX (1989), nr 6 (226), s. 17-18; (Suplement cz. 2), „Opole”, R. XX (1989), nr 7 (227), s. 17-18. 
oświatowo-wychowawczą, świetlicową, śpiewaczo-muzyczną, taneczną, teatralną oraz pracę Sekcji Literacko-Artystycznej ${ }^{136}$.

Kolejny artykuł przybliżył historię Festiwalu Piosenki Polskiej w Czechosłowacji. W festiwalach tych uczestniczyli również goście z Polski, jak Marek Grechuta z zespołem „Anawa” czy Halina Frąckowiak ${ }^{137}$. Emil Sztabla pisał o szkolnictwie polskim w Czechosłowacji ${ }^{138}$. Inny artykuł, również zamieszczony w „WDJ”, pt. Aktywni zawsze potrzebni przedstawił dr. Józefa Macurę, zasłużonego nauczyciela, działacza oświatowego, członka Zarządu Głównego PZKO ${ }^{139}$. Z kolei Korneliusz Pszczyński opisał dwa dni pobytu Zespołu Pieśni i Tańca „Olza”, który koncertował w 1983 r. na Opolszczyźnie. Autor przybliżył program występów oraz charakter i krótką historię zespołu ${ }^{140}$.

Zenon Jasiński był autorem artykułu o szkolnictwie polskim w czeskiej części Śląska Cieszyńskiego oraz o kursach organizowanych dla nauczycielach polskich z Czechosłowacji w Polsce, które umożliwiały zapoznanie się z problemami gospodarczymi, polską oświatą, nauką i kulturą ${ }^{141}$. W tym samym numerze Bernard Waleński opisał pobyt na „Święcie Gorolskim”, organizowanym przez PZKO w Czechosłowacji, przede wszystkim przez rzeszę społeczników, którzy rokrocznie przygotowywali tę najważniejszą dla Polaków imprezę na Zaolziu ${ }^{142}$. Życie literacko-artystyczne na Zaolziu było głównym tematem artykułu Bolesława Zarzecznego. Autor zaczął od wyjaśnienia terminu „Zaolzie”, następnie przedstawił historię działalności kulturalnej mniejszości polskiej po 1920 r., opisał również aktywność Sekcji Literacko-Artystycznej ${ }^{143}$.

W czwartym numerze „WDJ” z 1984 r. zamieszczono wiersze: Jana Kubisza, Pawła Kubisza, Henryka Jasiczka, Władysława Sikory, Wilhelma Przeczka, Gustawa Sajdoka, Janusza Gaudyma, Gabriela Palowskiego, Jana Pyszki, Tadeusza Wantuły, Jana D. Zolicha, Kazimierza Kaszpera, Jacka Sikory, Renaty Putzlacher, Lucyny Przeczek i Władysława Młynka ${ }^{144}$.

136 K. Santarius, Polski Zwiazek Kulturalno-Oświatowy w Czechosłowacji, „Wczoraj, Dzisiaj, Jutro”, R. VI (1972), nr 2/19, s. 91-97.

137 H. Kowalczyk, XI Festiwal Piosenki Polskiej, „Wczoraj, Dzisiaj, Jutro”, R. VIII (1974), nr 2/27, s. 55-59.

138 E. Sztabla, Szkolnictwo polskie w Czechosłowacji, „Wczoraj, Dzisiaj, Jutro”, R. VIII (1974), nr 4/29, s. 14-17.

139 Z. Jasiński, Aktywni wszędzie potrzebni, „Wczoraj, Dzisiaj, Jutro”, R. XI (1977), nr 3/40, s. 38-41.

140 K. Pszczyński, Dwa dni z „Olzq”, „Wczoraj, Dzisiaj, Jutro”, R. XVII (1983), nr 4/65, s. 39-42.

141 Z. Jasiński, Kurs dla nauczycieli polskich z Czechosłowacji, „Wczoraj, Dzisiaj, Jutro”, R. XVIII (1984), nr 3/68, s. 28-32.

142 B. Waleński, W Jabłonkowie chcq, „Wczoraj, Dzisiaj, Jutro”, R. XVIII (1984), nr 3/68, s. 33-35.

143 B. Zarzeczny, Życie literacko-artystyczne n Zaolziu, „Wczoraj, Dzisiaj, Jutro”, R. XVIII (1984), nr 4/69, s. 31-39.

144 „Wczoraj, Dzisiaj, Jutro”, R. XVIII (1984), nr 4/69, s. 40-65. 
W kolejnym roku na łamach „WDJ” chóry zaolziańskie „Harfę” i „Lirę” przybliżył Piotr Świerc ${ }^{145}$. W tym samym numerze zaczął się ukazywać cykl artykułów „Listy zza Olzy”, którego autorem był Leszek Kara. Dotyczyły one życia kulturalnego Polaków za Olzą i kontaktów z Polską ${ }^{146}$. W kolejnych artykułach opisywał Festiwal PZKO w Trzyńcu ${ }^{147}$ oraz animatorów kultury cieszyńskiej, podkreślając, jak ważna dla mieszkańców ziemi cieszyńskiej jest kultura ludowa, będąca dokumentem, narzędziem pracy i środkiem oddziaływania ${ }^{148}$. Następnie L. Kara przybliżył jubileusze chórów zaolziańskich „Lira” i „Hejno-Echo”, 70. rocznicę urodzin pierwszego redaktora naczelnego "Głosu Ludu”, działacza społecznego Andrzeja Kubisza ${ }^{149}$ oraz Klubu Młodych „Groń”, działającego przy Miejscowym Kole PZKO w Bystrzycy, który z czasem stał się prawdziwą kuźnią młodych społeczników ${ }^{150}$. Nie zapomniano również o 40. rocznicy działalności PZKO ${ }^{151}$.

Leszek Kara opisał również Scenę Polską z Czeskiego Cieszyna, okazją do przypomnienia historii tego teatru był jubileusz 35-lecia istnienia ${ }^{152}$, omówił działalność fotografików i plastyków zrzeszonych w SLA istniejącej przy PZKO. Zajął się także Jesiennym Seminarium Literackim SLA, w czasie którego Jan Pyszko omówił twórCzość opolskiego poety Jana Goczoła ${ }^{153}$ oraz jubileusz PZKO. Dokonania PZKO były imponujące, a zaczęto wszystko od budowy świetlic, które stwarzały dogodne warunki działalności kulturalno-oświatowej, co działacze skrzętnie wykorzystywali, i stale tętniło w nich życie, „w dni świąteczne i na co dzień brzmi w nich śpiew i słowo polskie"154.

Kolejne jubileusz to 25-lecie Grupy Literackiej '63 powołanej w Trzyńcu. Był to wyraz buntu młodych literatów: Janusza Gaudyma, Wilhelma Przeczka, Adama Wawrosza, Alojzego Mainki, Gustawa Sajdoka, Bronisława Bielana i Józefa Krzywonia. Z okazji ćwierćwiecza GL'63 wydała publikację zbiorową pt. Samosiewy ${ }^{155}$.

145 P. Świerc, Zaolziańskie chóry na Opolszczyźnie, „Wczoraj, Dzisiaj, Jutro”, R. XIX (1985), nr 1-2/70-71 S. 92-94.

146 L. Kara, List zza Olzy, „Wczoraj, Dzisiaj, Jutro”, R. XIX (1985), nr 1-2/70-71, s. 133-139.

147 Idem, Festiwal PZKO w Trzyńcu. List zza Olzy, „Wczoraj, Dzisiaj, Jutro”, R. XIX (1985), nr 3/72, s. 62-64.

148 Idem, Badacze i animatorzy kultury ziemi cieszyńskiej. List z Zaolzia, „Wczoraj, Dzisiaj, Jutro”, R. XIX (1985), nr 4/73, s. 58-64.

149 Idem, Jubileusze chórów i Andrzeja Kubisza. List zza Olzy, „Wczoraj, Dzisiaj, Jutro”, R. XX (1986), nr 1-2/86, s. 143-148.

150 Idem, Kuźnia młodych społeczników, „Wczoraj, Dzisiaj, Jutro”, R. XX (1986), nr 3/86, s. 77-82.

151 (FA), Co dzień Polak narodowi służy! List zza Olzy, „Wczoraj, Dzisiaj, Jutro”, R. XX (1986), nr 4/77, s. 73-74.

152 L. Kara, Święto teatru. Listy zza Olzy, „Wczoraj, Dzisiaj, Jutro”, R. XXI (1987), nr 2-3/87, s. 130-138.

153 Idem, Bogate życie artystów. Listy zza Olzy, „Wczoraj, Dzisiaj, Jutro”, R. XXI (1987), nr 4/81, s. 95-98.

154 Idem, Jubileusz PZKO. Listy zza Olzy, „Wczoraj, Dzisiaj, Jutro”, R. XXII (1988), nr 1-2 (82-83), s. 136-144.

155 Idem, Ćwierćwiecze Grupy Literackiej'63. Listy zza Olzy, Wczoraj, Dzisiaj, Jutro", R. XXII (1988), nr 3-4 (84-85), s. 117-120. 
W tym samym numerze ukazał się artykuł z okazji jubileuszu 70. urodzin jednego z czołowych nestorów zaolziańskiego życia śpiewaczo-muzycznego Józefa Firli ${ }^{156}$, 80-lecia Gimnazjum w Orłowej, 40-lecia Gimnazjum w Czeskim Cieszynie, 35-lecia Polskiego Zespołu Śpiewaczego „Hutnik” oraz 35-lecia Zespołu Pieśni i Tańca „Olza”157.

W roku 1989 Leszek Kara opublikował artykuły dotyczące odsłonięcia na wzgórzu zamkowym w Cieszynie pomnika nauczyciela, poety i społecznika Jana Kubisza ${ }^{158}$; życia i działalności Emanuela Guziura ${ }^{159}$; uhonorowania zespołu Sceny Polskiej Teatru Cieszyńskiego Medalem Pamiątkowym ZASP-u ${ }^{160}$ oraz XX Festiwalu Piosenki Polskiej w Czechosłowacji ${ }^{161}$.

Książka Gustawa Sajdoka Zaczarowany młynek była przedmiotem analizy Zygmunta Kętrzyńskiego. Autor posługiwał się w swoich wierszach dla dzieci obrazem baśni, aby rozśmieszyć maluchy, którym przyszłość każe poznawać świat poprzez znajomość języka polskiego ${ }^{162}$, natomiast Władysław Hendzel zaprezentował czytelnikom tomik wierszy Malinowy świat Anieli Kupiec ${ }^{163}$, a Zygmunt Kętrzyński przedstawił Samosiewy, almanach Grupy Literackiej '63 ${ }^{164}$. Z kolei Ludwik Kozołub w „Listach zza Olzy” przybliżył postać dr. Józefa Wierzgonia ${ }^{165}$.

W „Kalendarzu Opolskim” również opublikowano serię artykułów na temat życia Polaków na Zaolziu oraz współpracy PZKO z OTKO i z poszczególnymi towarzystwami regionalnymi. W roczniku tym, oprócz dokładnie prowadzonej kroniki dokumentującej współpracę społeczeństwa Śląska Opolskiego z Polakami na Zaolziu, drukowane były także artykuły o tematyce zaolziańskiej. Franciszek Adamiec zdał relację z wizyty opolskiej delegacji na Zaolziu, która zapoznała się z ciekawymi ludźmi i formami pracy kulturalnej i oświatowej naszych rodaków w Czechosłowacji166.

W „Kalendarzu Opolskim” znalazł się też przedruk artykułu o zespołach regionalnych PZKO działających na Zaolziu, które wcześniej przedstawiła Anna Wacławik

156 Idem, Jubileusz Józefa Firli, „Wczoraj, Dzisiaj, Jutro”, R. XXII (1988), nr 3-4/84-85, s. 121-125.

157 Idem, Pod znakiem jubileuszy. List zza Olzy, „Wczoraj, Dzisiaj, Jutro”, R. XXIII (1989), nr 4 (89), s. 38-48.

158 Idem, Pomnik Jana Kubisza w Cieszynie. List zza Olzy, „Wczoraj, Dzisiaj, Jutro”, R. XXIII (1989), nr 1 (86), s. $77-78$

159 Idem, Odszedł Emanuel Guziur. List zza Olzy, „Wczoraj, Dzisiaj, Jutro”, R. XXIII (1989), nr 1 (86), s. 78-79.

160 Idem, Uhonorowanie Sceny Polskiej TC. List zza Olzy, „Wczoraj, Dzisiaj, Jutro”, R. XXIII (1989), nr 1 (86), s. 80 .

161 Idem, Jubileuszowy FPP w Karwinie, „Wczoraj, Dzisiaj, Jutro”, R. XXIII (1989), nr 2-3 (87-88), s. 102-103.

162 Z. Kętrzyński, W kręgu magicznych rymowanek, „Wczoraj, Dzisiaj, Jutro”, R. XXII (1988), nr 1-2 (8283), s. 118-119.

163 W. Hendzel, Zagubiona w beskidzkim pejzażu, „Wczoraj, Dzisiaj, Jutro”, R. XXIII (1989), nr 1(86), s. 56-59.

164 Z. Kętrzyński, Samosiewy nad Olzq, „Wczoraj, Dzisiaj, Jutro”, R. XXIII (1989), nr 1(86), s. 59-60.

165 L. Kozołub, Krzewiciel kultury polskiej w Czeskim Cieszynie. Listy zza Olzy, „Wczoraj, Dzisiaj, Jutro”, R. XXIII (1989), nr 2-3 (87-88), s. 98-101.

166 F. Adamiec, Z wizytq za Olzq, Kalendarz Opolski" 1973, Opole 1972, s. 341. 
w jednodniówce Cudze chwalicie - swego nie znacie, wydanej z okazji 5-lecia Sekcji Folklorystycznej przy Zarządzie Głównym PZKO'167, począwszy od najstarszego chóru „Gorol”, poprzez Zespół Pieśni i Tańca „Górnik” i „Olza”, następnie zespół „Przełęcz”, „Sibica”. Autorka uważała, że Polacy na Zaolziu będą „stale wracać do tradycji, do tych zabytków i klejnotów twórczości ludowej, które wytworzyły kiedyś dla nas czyste i gorące serca naszych przodków"168.

Historia lotników Franciszka Żwirki i Stanisława Wigury była tematem artykułu Józefa Stebla. Bezpośrednio po katastrofie powstał wśród miejscowej polskiej ludności Komitet Budowy Pomnika Żwirki i Wigury. Pod pomnik przychodzą turyści z Czechosłowacji i z Polski ${ }^{169}$.

Życie i działalność Polaków w Łomnej Dolnej przedstawiła Halina Kowalczyk, pisała o szkole, przybliżyła imprezy organizowane w ciągu roku przez Koło PZKO ${ }^{170}$.

Działalnością PZKO zajmował się także Henryk Szmeja. Gwałtowne uprzemysłowienia okręgu przyczyniło się do procesów migracyjnych, które nie ominęły również ludności polskiej. Powstały nowe osiedla, zmianie uległa też problematyka kulturalno-społeczna i narodowa. W związku z innym podejściem do organizacji wolnego czasu, PZKO musi stwarzać także różnorodne warunki, by poszczególne generacje i grupy społeczne mogły się realizować kulturowo ${ }^{171}$.

Kolejny artykuł przedstawił sylwetki, twórczość oraz kontakty Wilhelma Przeczka i Kazimierza Kaszpera z Opolszczyzną. Poeci ci od dawna ściśle współpracowali z literatami, młodzieżą i towarzystwami regionalnymi Opolszczyzny ${ }^{172}$. Na łamach „Kalendarza Opolskiego" zamieszczone zostały wybrane utwory Wilhelma Przeczka ${ }^{173}$, Kazimierza Kaszpera ${ }^{174}$, Jacka Sikory ${ }^{175}$, Władysława Sikory ${ }^{176}$ i Jana Pyszki ${ }^{177}$.

167 A. Wacławik, Nasze zespoły folklorystyczne, [w:] Cudze chwalicie - swego nie znacie, red. J. Ondrusz, Czeski Cieszyn 1970, s. 29-31.

168 Idem, Nasze zespoły regionalne, „Kalendarz Opolski” 1973, Opole 1972, s. 342-344.

169 J. Stebel, Żwirowisko, „Kalendarz Opolski” 1973, Opole 1972, s. 345-348.

170 H. Kowalczyk, Wsi spokojna, wsi wesoła..., „Kalendarz Opolski” 1975, Opole 1975, s. 262-265.

171 H. Szmeja, 30 lat pracy nad utrwalaniem przyjaźni czechosłowacko-polskiej, „Kalendarz Opolski” 1979, Opole 1979, s. 225-229.

172 j.st., Dwaj poeci z Zaolzia, „Kalendarz Opolski” 1981, s. 163-164.

173 W. Przeczek, Wycinanki, Kompas wmurowany w fundament pomnika, „Kalendarz Opolski” 1981, Opole 1981 , s. 165 i 168.

174 K. Kaszper, W orszaku, „Kalendarz Opolski” 1981, Opole 1981, s. 165.

175 J. Sikora, ***, ,Kalendarz Opolski” 1986, Opole 1986, s. 129.

176 W. Sikora, Ubezpieczeni na życie, „Kalendarz Opolski” 1986, Opole 1986, s. 130; Zakładanie kapusty, „Kalendarz Opolski” 1986, Opole 1986, s. 137.

177 J. Pyszko, Żywocie, „Kalendarz Opolski” 1987, Opole 1987, s. 257-258. 
Z okazji XIV Zjazdu PZKO w Czeskim Cieszynie Franciszek Adamiec przypomniał historię tej organizacji. W artykule znalazł się obszerny opis samego przebiegu zjazdu ${ }^{178}$.

W 1984 r. upłynęło sto lat od założenia jednej z najbardziej zasłużonych na Śląsku Cieszyńskim organizacji - Macierzy Szkolnej dla Księstwa Cieszyńskiego. Stanisław Zahradnik przypomniał jej historię i dorobek wydawniczy ${ }^{179}$.

Swoje przeżycia z wyprawy do Czechosłowacji przedstawiła Jadwiga Orłowska, która odwiedziła m.in. Cierliko, miejsce, gdzie stoi pomnik poświęcony polskim lotnikom Żwirce i Wigurze. Autorka w trakcie swej podróży po Zaolziu odwiedziła poszczególne miejsca związane z Polską i opisała je ${ }^{180}$.

Janina Hajduk-Nijakowska w artykule przybliżyła obchody 40-lecia działalności PZKO i w związku z tym odwiedziny twórców zaolziańskich na Opolszczyźnie m.in. podczas „Dnia PZKO”181. Zaprosiła również do zapoznania się tym razem z twórczością prozatorską Zaolziaków: Władysława Sikory ${ }^{182}$, Kazimierza Jaworskiego ${ }^{183}$ i Wiesława Adama Bergera ${ }^{184}$, prezentowaną w 1988 r. w „Kalendarzu Opolskim”.

Z opolskiej prasy zakładowej jedynie pismo "Głos Włókniarza” systematycznie zamieszczało publikacje o współpracy z PZKO, a zwłaszcza z kołem w Datyniach Dolnych. W „Głosie Włókniarza” ukazywały się odrębne, jednoarkuszowe wkładki, przygotowane przez działaczy PZKO z Datyń Dolnych. Wkładki te ilustrowane były przez zespół redakcyjny „Głosu Włókniarza” i członków Zakładowego Koła Kultury ${ }^{185}$.

Z kolei w Czechosłowacji miesięcznik Zarządu Głównego PZKO „Zwrot” zamieszczał artykuły o tematyce opolskiej. Na jego łamach znalazły się utwory opolskich poetów, m.in. Jana Goczoła ${ }^{186}$, Bogusława Żurakowskiego ${ }^{187}$, Marka Jodłowskiego ${ }^{188}$,

178 F. Adamiec, Byliśmy na XIV Zjeździe Polskiego Zwiqzku Kulturalno-Oświatowego w Czeskim Cieszynie, „Kalendarz Opolski” 1984, Opole 1984, s. 203-234.

179 S. Zahradnik, Macierz Szkolna w Czechosłowacji, „Kalendarz Opolski” 1986, Opole 1986, s. 130-136.

180 J. Orłowska, Na trasie E-7, „Kalendarz Opolski” 1986, Opole 1986, s. 137-142.

181 J. Hajduk-Nijakowska, Słowo polskie z Zaolzia, „Kalendarz Opolski” 1988, Opole 1988, s. 191-192.

182 W. Sikora, Amazonka, „Kalendarz Opolski” 1988, Opole 1988, s. 193-195.

183 K. Jaworski, Los, „Kalendarz Opolski” 1988, Opole 1988, s. 196-198.

184 W.A. Berger, Jaworski nad Mare Negro, „Kalendarz Opolski” 1988, Opole 1988, s. 199-201.

185 WBP Opole, Protokoły z posiedzeń Prezydium Zarządu OTKO i Zarzadu OTKO 1979 r., sygn. 95, Kontakty Opolskiego Towarzystwa Kulturalno-Oświatowego z Polakami z Polskiego Związku Kulturalno-Oświatowego w Czechosłowacji (1978), s. 4.

186 J. Goczoł, Ta słodycz życia, „Zwrot”, R. XXIV (1972), nr 8 (273), s. 30.

187 B. Żurakowski, Przewodnik, „Zwrot”, R. XXIV (1972), nr 8 (273), s. 30; idem, Inwokacja, „Zwrot”, R. XXV (1972), nr 1 (278), s. 42 [okładka]; idem, Portret czasu, „Zwrot”, R. XXIX (1977), nr 5 (330), s. 36; idem, XXX [Wszystko odbywa się bez uszczerbku], „Zwrot”, R. XXXI (1979), nr 1 (350), s. 48.

188 M. Jodłowski, Kalendarz Bruegla, „Zwrot”, R. XXIV (1972), nr 3 (268), s. [42 okładka]; idem, Osad, „Zwrot”, R. XXIV (1972), nr 8 (273), s. 30; idem, Asfalt, jego właściwości i przeznaczenie, „Zwrot”, R. XXVII (1975), nr 6 (307), s. 9; idem, Czarnym długopisem, „Zwrot”, R. XXIX (1977), nr 12 (337), s. 13. 
Tadeusza Soroczyńskiego ${ }^{189}$, Jana Goczoła ${ }^{190}$ i Harry'ego Dudy ${ }^{191}$. Zamieszczane tam też były Listy z Opola Edwarda Pochronia, w których autor podjął temat współpracy PZKO z instytucjami na Opolszczyźnie. Okazją do tego była m.in. wystawa plastyków ze SLA przy PZKO, która miała miejsce w Opolu w 1974 r. W artykule zaprezentowane zostało również opolskie środowisko plastyczne skupione w Oddziale Związku Polskich Artystów Plastyków w Opolu ${ }^{192}$. W kolejnych Listach z Opola autor poinformował czytelników o zmianach zachodzących w Opolu, zarówno w architekturze miasta, jak i w dziedzinie kultury. Pisał m.in. o IV Opolskich Konfrontacjach Teatralnych odbywających się w Teatrze im. J. Kochanowskiego w Opolu oraz o laureatach nagrody dziennikarskiej, którą po raz pierwszy wręczono podczas święta „Trybuny Odrzańskiej” ${ }^{193}$. Innym razem Edward Pochroń podzielił się przemyśleniami na temat kultury ludowej na Opolszczyźnie ${ }^{194}$, by następnie w całości poświęcić artykuł teatrowi i Opolskim Konfrontacjom Teatralnym ${ }^{195}$.

Halina Kowalczyk na łamach „Zwrotu” w rozmowie z Karolem Musiołem przypomniała czytelnikom początki Krajowego Festiwalu Piosenki Polskiej w Opolu ${ }^{196}$.

Korneliusz Pszczyński opisał wystawę Gustawa Fierli, która miała miejsce w 1976 r. salonie BWA w Opolu. Autor wystawy to znany na Zaolziu etnograf, muzealnik, działacz społeczno-kulturalny, pedagog, publicysta, a przede wszystkim artysta $^{197}$. Następnie Korneliusz Pszczyński zaprezentował wystawę otwartą w KZT w Opolu. Jej autorem był Bronisław Firla, architekt i plastyk z zawodu ${ }^{198}$. Kolejna wystawa w KZT w Opolu eksponowała ekslibrysy Zbigniewa Kubeczki wykonane dla wielu działaczy mniejszości polskiej na Zaolziu, m.in. dla Bronisława Bielana, Franciszka Bałona, Gustawa Firli, Franciszka Świdra i in. ${ }^{199}$, a w BWA otwarta została wystawa pod tytułem „Plastyka z Czeskiego Cieszyna”, były to prace m.in. Gustaw

189 T. Soroczyński, Uwertura lipcowa, „Zwrot”, R. XXIX (1977), nr 7 (332), s. 5; idem, W dolinie Olzy, "Zwrot”, R. XXXI (1979), nr 1 (350), s. 32; idem, XXX [wracamy do słów najpierwszych], Erotyk zielony, Monolog, Noszę te słowa, „Zwrot”, R. XXXVIII (1986), nr 10 (443), s. 30.

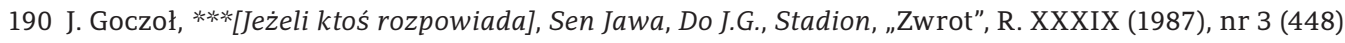
S. $42-43$

191 H. Duda, Na Potoku w Jabłonkowie u Jana, Z domu towarowego w Jabłonkowie pocztówka, Olza, Z wizytq u zmarłych w Jabłonkowie, W kotlinie Jabłonkowa, Cieszyńsko-Jabłonkowski wiersz biesiadny, „Zwrot”, R. XXXIX (1988), nr 1 (458), s. 30-31.

192 E. Pochroń, List z Opola, „Zwrot”, R. XXVII (1975), nr 2 (303), s. 38-39.

193 Idem, O rekonstrukcji Opola, teatrze i dziennikarzach, „Zwrot”, R. XXX (1978), nr 8 (345), s. 12-13.

194 Idem, Kultura ludowa - żywa, „Zwrot”, R. XXXI (1979), nr 1 (350), s. 31-32.

195 Idem, Opolanie lubiq klasykę, „Zwrot”, R. XXXI (1979), nr 7 (356), s. 54-55.

196 H. Kowalczyk, Festiwal bez przebojów?, „Zwrot”, R. XXVIII (1976), nr 7 (320), s. 11-12.

197 K.P. Pszczyński, W środę 7 lipca 1976 roku w salonie, „Zwrot”, R. XXVIII (1976), nr 8 (321), s. 40-41.

198 Idem, Wystawa Bronisława Firli w Opolu, „Zwrot”, R. XXIX (1977), nr 6 (331), s. 51.

199 Idem, Ekslibrysy w Opolu, „Zwrot”, R. XXXI (1979), nr 2 (351), s. 75. 
Firli, Dominika Figurnego, Bronisława Firli, Stanisława Krausa, Władysława Pasza, Oskara Pawlasa, Karola Piegzy ${ }^{200}$.

W „Zwrocie” znajdują się także informacje na temat współpracy PZKO z OTKO i TPO, m.in. o ufundowaniu statuetki „Karolinki” oraz sfinansowaniu pobytu w charakterze gościa na KFPP w Opolu ${ }^{201}$. Wilhelm Przeczek przedstawił czytelnikom „Zwrotu” sylwetkę i twórczość Bogusława Żurakowkiego ${ }^{202}$. Kolejny artykuł poświęcony był pobytowi chóru mieszanego „Lira” na Opolszczyźnie. Występy „Liry” zapoczątkowały prezentacje innych zaolziańskich zespołów na Śląsku Opolskim w ramach współpracy OTKO i PZKO 203.

O swoich przeżyciach podczas pierwszego pobytu w Opolu pisał Wiesław Adam Berger. Z życzliwością wspominał serdeczność, z jaką został przyjęty przez przedstawicieli OTKO oraz słuchaczy na wieczorku literackim w KZT204.

W miesięczniku „Zwrot” zamieszczano również recenzje książek wydawanych w Opolu, dotyczących m.in. Śląska Opolskiego. Jedną z nich była praca Stanisława Wasilewskiego pt. $\mathrm{Na}$ Ślq̨sku Opolskim, opublikowana przez Instytut Śląski ${ }^{205}$.

Zainteresowanie opolskich historyków problematyką polskiej mniejszości narodowej na Zaolziu było przedmiotem analizy Stanisława Zahradnika, który na łamach „Zwrotu” przybliżył działania w tym względzie Zenona Jasińskiego. Zrecenzował m.in. pokonferencyjną publikację o przenikaniu się kultur ${ }^{206}$ oraz pracę na temat działalności kulturalno-oświatowej Polaków za Olzą ${ }^{207}$, następnie opisał przygotowania do wydania Leksykonu Polaków w Czechosłowacji ${ }^{208}$.

Literaci zaolziańscy utrzymywali stały kontakt ze środowiskiem literackim Opolszczyzny, byli bowiem członkami ZLP, Oddział w Opolu. Jednym z nich był Wilhelm Przeczek z Bystrzycy nad Olzą. Z kolei opolscy literaci często gościli na Zaolziu, m.in. byli zapraszani do „Kawiarenki pod Pegazem”, na spotkania z literaturą polską, odbywające się w ramach Gorolskiego Święta w Jabłonkowie, gdzie rokrocznie spotykali się miłośnicy polskiej poezji. W ramach „Kawiarenki” swoje wieczory

200 Idem, Plastyka z Czeskiego Cieszyna na Opolszczyźnie, „Zwrot”, R. XXXII (1980), nr 12 (373), s. 61.

201 -hak-, Inny smak XV FPP, „Zwrot”, R. XXXI (1979), nr 5 (354), s. 62-63.

202 W. Przeczek, Bogusław Żurakowski, „Zwrot”, R. XXXI (1979), nr 1(350, s. 46-48.

203 (kara), „Lira” na Opolszczyźnie, „Zwrot”, R. XXVI (1984), nr 2 (420), s. 19.

204 W.A. Berger, Opole...Opole, „Zwrot”, R. XXXVIII (1986), nr 8 (441), s. 20-21.

205 W. Josiek, rec. S. Wasylewski, Na Ślq̨sku Opolskim, „Zwrot”, R. XXXX (1988), nr 11 (468), s. 48-49.

206 S. Zahradnik, Zderzenia i przenikanie kultur na pograniczach, rec. Zderzenia i przenikanie kultur na pograniczach. Materiały z konferencji naukowej w Opolu, 19-20.10.1987, red. Z. Jasiński, J. Korbel, Opole 1989, „Zwrot”, R. XLII (1990), nr 1 (482), s. 56-58.

207 Idem, O międzywojennej działalności kulturalno-oświatowej Polaków na Zaolziu, rec. Z. Jasiński Działalność kulturalno-oświatowa Polaków za Olzq 1920-1938, Opole 1990, „Zwrot”, R. XLII (1990), nr 8 (489), s. $56-58$.

208 Idem, Leksykon Polaków w Czechosłowacji, Opole 1990, „Zwrot”, R. XLII (1990), nr 2 (482), s. 62-63. 
mieli także opolscy literaci: Harry Duda, Tadeusz Soroczyński, Wiesław Malicki, Janusz Wójcik, Irena Wyczółkowska, Elżbieta Lisak-Duda, Jan Goczoł209.

OTKO utrzymywało bliskie kontakty z PZKO w Czechosłowacji. W Opolu i na Opolszczyźnie podejmowani byli mieszkający w Czechosłowacji polscy twórcy - poeci, plastycy, fotograficy. Aby poznać genezę ich twórczości i warunki pracy twórczej, OTKO wydało publikację pt. Suita zaolziańska, w której przedstawiono twórczość literacką Polaków w Czechosłowacji ${ }^{210}$. Przez kolejne lata OTKO starało się publikować prace literatów zaolziańskich. W roku 1986 wydane zostały przez OTKO i Wydział Kultury i Sztuki Urzędu Wojewódzkiego w Opolu, zebrane przez Daniela Kadłubca, cieszyńskie piosenki ludowe ${ }^{211}$.

W ramach kontaktów wychodziły w Opolu publikowane przez Instytut Śląski oraz Wyższą Szkołę Pedagogiczną książki traktujące o historii Polaków mieszkających w Czechosłowacji, dotyczące ruchu oporu na Śląsku Cieszyńskim ${ }^{212}$, czasów II wojny światowej ${ }^{213}$ oraz aktywności kulturalno-oświatowej Polaków żyjących w tej części Śląska Cieszyńskiego, która w wyniku decyzji Rady Ambasadorów w 1920 r. przypadła Czechosłowacji ${ }^{214}$. Publikację dotyczącą czasopiśmiennictwa polskiego w Czechosłowacji przygotował Stanisław Zahradnik. W skomplikowanych warunkach społeczno-narodowych prasa miała szczególne znaczenie. Była przede wszystkim wyrazem aktywności społecznej danej narodowości ${ }^{215}$.

Znawcą kultury mniejszości narodowej na Zaolziu jest bez wątpienia Zenon Jasiński, który od lat $80 . \mathrm{XX}$ w. zajmował się tą tematyką. To on był pomysłodawcą Leksykonu Polaków w Czechosłowacji, w którym w formie haseł przedstawił całe spektrum życia mniejszości polskiej za Olzą, ukazując sylwetki działaczy, instytucje i organizacje, miejscowości zamieszkałe przez polską narodowość. Pierwszy zeszyt próbny leksykonu ukazał się w 1983 r., trzy lata później powstała publikacja, która była pokłosiem konferencji poświęconej aspektom metodologicznym programu badawczego pt. „Leksykon Polaków w Czechosłowacji” ${ }^{216}$. W roku 1990 opublikowane zostało wydawnictwo będące efektem wieloletnich prac z wyżej wymienionego programu badawczego. We wstępie do tej książki Zenon Jasiński napisał: „Poprzez program: Leksykon Polaków w Czechosłowacji pragniemy uchronić od zapomnienia

209 J. Pyszko, Kawiarenka pod Pegazem 1989-2002, Jabłonków 2003, s. 225-227.

210 Suita zaolziańska, Opole 1985.

211 D. Kadłubiec, Z biegiem Olzy, Opole 1986.

212 M. Haller, Ruch oporu na Ślq̨sku Cieszyńskim, Opole 1982.

213 S. Zahradnik, Zaolziańskie ofiary okupacji hitlerowskiej (w byłych powiatach czeskocieszyńskim i frysztackim) 1939-1945, Opole 1988

214 Z. Jasiński, Działalność kulturalno-oświatowa Polaków za Olzq 1920-1938, Opole 1990.

215 S. Zahradnik, Czasopiśmiennictwo w języku polskim na terenach czechosłowackich, Opole 1989.

216 Leksykon jako koncepcja badań nad zbiorowościq polonijnq w Czechosłowacji, red. Z. Jasiński, Opole 1986. 
dorobek materialny i duchowy mieszkańców Zaolzia, jak i Polaków rozproszonych po całej Czechosłowacji"217. Po kolejnej konferencji na temat problematyki mniejszości narodowych, której inicjatorem był również Zenon Jasiński, powstała publikacja, w której większość materiałów dotyczyła problematyki zaolziańskiej ${ }^{218}$. Na tym wydawnictwie badania nad mniejszością polską się nie zakończyły. Profesor Zenon Jasiński skompletował zespół naukowców, redaktorów i animatorów kultury, którzy przez następne lata zbierali materiały do wielotomowego wydawnictwa Leksykon Polaków w Republice Czeskiej i Republice Słowackiej.

\section{Wystawy}

Opolszczyzna z Zaolziem współdziałała również na niwie plastyki. Twórcy przyjeżdżali na Śląsk Opolski z autorskimi wystawami lub brali udział w plenerach malarskich. Dorobek członków SLA opolanie mogli poznać, nie przekraczając granicy. Co parę lat BWA w Opolu organizowało wystawy środowiska plastycznego, a mniej więcej raz do roku - indywidualne, autorskie ${ }^{219}$.

Plastycy zaolziańscy skupieni w SLA PZKO często prezentowali swoje prace w salonie BWA w Opolu. Czasem były one połączone z wieczorami literackimi w KZT, plastycy i literaci wspólnie przedstawiali opolanom zaolziańskie plakaty poetyckie. Podczas „Dnia PZKO” na Opolszczyźnie w 1987 r. w Wojewódzkim Domu Kultury otwarto wystawę prac fotograficznych autorów zgrupowanych w SLA, w imieniu których oprowadzał gości po wystawie prezes Klubu Fotograficznego Franciszek Bałon. W KMPiK odbył się wernisaż ekspozycji pn. „Zaolziańska plastyka ludowa”, na której znalazły się m.in. ciekawe rzeźby Bronisława Procnera. Największym zainteresowaniem opolan cieszyła się jednak wystawa „Polskie słowo na Zaolziu”, którą zorganizowała WBP ${ }^{220}$. Prezes Zarządu Głównego PZKO - Stanisław Kondziołka podczas otwarcia tej wystawy powiedział m.in.:

Robimy wszystko, by język polski na Zaolziu był językiem żywym i twórczym. Staramy się o to, by zachować kulturowy charakter naszego regionu, sięgający korzeniami kultury polskiej, bo tak rozumiemy naszą odpowiedzialność wobec przeszłości, jak i wobec pokoleń i przyszłości. Cieszy nas, że mamy w tym serdeczne i szerokie wsparcie Opola i OTKO ${ }^{221}$.

217 Z. Jasiński, Mały leksykon nadolziański, Opole 1990.

218 Zderzenia i przenikanie kultur na pograniczach. Materiały z konferencji naukowej w Opolu, 19-20.10.1987, red. Z. Jasiński, J. Korbel, Opole 1989.

219 Polacy spoza Polski, „Opole”, R. XIV (1983), nr 12 (160), s. 26.

220 T. Soroczyński, Opolskie Towarzystwo Kulturalno-Oświatowe. Kronika ruchu regionalnego kwiecieńwrzesień 1987 r., „Wczoraj, Dzisiaj, Jutro”, R. XXI (1987), nr 4 (81), s. 82.

221 (jak), Opolskie Dni PZKO, „Wczoraj, Dzisiaj, Jutro”, R. XXI (1987), nr 4 (81), s. 29-31. 
Opolscy plastycy kontaktowali się również z działaczami SLA i patronowali ich imprezom, urządzanym głównie w Klubie Związków Twórczych i BWA ${ }^{222}$. W salonie BWA swoje prace prezentowali: Stanisław Kraus, Oskar Pawlas ${ }^{223}$, Józef Drong, Tadeusz Ramik $^{224}$, Tadeusz Berger, Bronisław Firla, Bronisław Liberda, Jan Szkwara. Odwiedzający wystawę mogli poznać grafikę, tkaniny, linoryty oraz obrazy olejne ${ }^{225}$.

W ramach „Lata Kwiatów”, odbywającego się w Otmuchowie, eksponowano także artystyczny efekt dwutygodniowego pleneru malarskiego dla amatorów, w którym od wielu lat brali udział plastycy z Czechosłowacji, członkowie PZKO ${ }^{226}$. W plenerze malarskim w Kędzierzynie-Koźlu uczestniczyli m.in. Józef Drong ${ }^{227}$ i Bronisław Fir$l^{228}$. Plenery fotograficzne odbywały się w Pokrzywnej z udziałem działaczy SLA PZKO z Czechosłowacji229.

\section{Pieśń polska - festiwale}

Kontakty z Zaolziem odbywały się poprzez uczestniczenie w różnego rodzaju festiwalach zarówno na Śląsku Opolskim, jak i na Zaolziu, oraz organizowanie występów zespołów artystycznych. Na Zaolziu rokrocznie przygotowywano wiele imprez, począwszy od festiwali zespołów PZKO ${ }^{230}$ po Święto Gorolskie, na których rozbrzmiewała polska pieśn. Corocznie delegacja z Opolszczyzny uczestniczyła

222 WBP Opole, Protokoły z posiedzeń Prezydium Zarządu OTKO i Zarządu OTKO 1979 r., sygn. 95, Kontakty Opolskiego Towarzystwa Kulturalno-Oświatowego z Polakami z Polskiego Związku Kulturalno-Oświatowego w Czechosłowacji (1978), s. 3.

223 T. Soroczyński, Opolskie Towarzystwo Kulturalno-Oświatowe. Kronika ruchu regionalnego, „Wczoraj, Dzisiaj, Jutro", R. XI (1978), nr 4/45, s. 74.

224 Materiały na IV Zjazd OTKO, Opole 1983, s. 43.

225 Wystawa Prac Polskich Plastyków w CSRS, „Opole”, R. III (1972), nr 8 (28), s. 33.

226 (s), Towarzystwo Miłośników Otmuchowa. Kronika ruchu regionalnego Kwiecień-wrzesień 1980, „Wczoraj, Dzisiaj, Jutro”, R. XIV (1980), nr 4/53, s. 97.

227 Opolskie Towarzystwo Kulturalno-Oświatowe, „Wczoraj, Dzisiaj, Jutro”, R. XIX (1985), nr 1-2 /70-71 s. 73-74; por. T. Soroczyński, oprac., Kronika społeczno-kulturalna wrzesień 1984 -sierpień 1985, „Kalendarz Opolski" 1986, Opole 1986, s. 217.

228 Działalność Opolskiego Towarzystwa Kulturalno-Oświatowego w 1988 roku, „Wczoraj, Dzisiaj, Jutro”, R. XXIII (1989), nr 2-3/87-88, s. 81.

229 T. Soroczyński, Opolskie Towarzystwo Kulturalno-Oświatowe. Kronika ruchu regionalnego (styczeńczerwiec 1988 r.), „Wczoraj, Dzisiaj, Jutro”, R. XXII (1988), nr 3-4/84-85, s. 115.

230 Idem, Opolskie Towarzystwo Kulturalno-Oświatowe. Kronika ruchu regionalnego kwiecień-wrzesień 1980, „Wczoraj, Dzisiaj, Jutro”, R. XIV (1980), nr 4/53, s. 89. 
w „Święcie Gorolskim” w Jabłonkowie ${ }^{231}$. Na tę największą imprezę folklorystyczną zapraszani byli przedstawiciele OTKO, TPO i Wydziału Kultury i Sztuki Urzędu Wojewódzkiego ${ }^{232}$.

Festiwal PZKO, który odbył się w Trzyńcu w 1974 r., przebiegał pod hasłem „Wszystko nas łączy", przygotowany z okazji 30-lecia Polski Ludowej, 30-lecia Słowackiego Powstania Narodowego oraz 30-lecia wyzwolenia Czechosłowacji. Był on kolejnym zlotem Polaków w Czechosłowacji oraz ich sympatyków, przekształcając się w masową demonstrację współpracy między narodami ${ }^{233}$.

W Czechosłowacji w Karwinie odbywał się również Festiwal Piosenki Polskiej (FPP). Każdego roku przedstawiciele OTKO i TPO uczestniczyli w FPP organizowanym przez Zarząd Główny PZKO oraz Rozgłośnię Radia Czechosłowackiego w Ostrawie, w którym główną nagrodą była statuetka „Karolinki” - rzeźba Mariana Nowaka nagroda TPO oraz udział jako gość na Krajowym Festiwalu Piosenki Polskiej (KFPP) w Opolu ${ }^{234}$. Festiwalom towarzyszyły recitale polskich piosenkarzy, m.in. Ewy Demarczyk ${ }^{235}$, Marka Grechuty z zespołem „Anawa” czy Haliny Frąckowiak ${ }^{236}$.

W swoim artykule o FPP Halina Kowalczyk zwróciła się z wnioskiem w 1974 r., aby zwycięzcom festiwalu, którzy do tej pory wyjeżdżali w nagrodę na KFPP do Opola w charakterze obserwatorów, umożliwić występ, chociażby na jakieś imprezie towarzyszącej festiwalowi ${ }^{237}$.

231 Materiały na IV Zjazd OTKO, Opole 1983, s. 45; por. T. Soroczyński, Opolskie Towarzystwo Kulturalno-Oświatowe. Kronika ruchu regionalnego kwiecień-wrzesień 1980, „Wczoraj, Dzisiaj, Jutro”, R. XIV (1980), nr 4/53, s. 92.

232 Kronika społeczno-kulturalna Ślaska Opolskiego (wrzesień 1985-sierpień 1986), oprac. T. Soroczyński, „Kalendarz Opolski” 1987, Opole 1987, s. 229; por. T. Soroczyński, Opolskie Towarzystwo Kulturalno-Oświatowe. Kronika ruchu regionalnego, „Wczoraj, Dzisiaj, Jutro”, R. XV (1981), nr 4/57, s. 78; idem, Opolskie Towarzystwo Kulturalno-Oświatowe. Kronika ruchu regionalnego kwiecień-wrzesień 1983, „Wczoraj, Dzisiaj, Jutro", R. XVII (1983), nr 4/65, s. 68.

233 W. Sikora, Festiwal PZKO 1974, „Kalendarz Opolski” 1975, Opole 1975, s. 259-262.

234 Zob. B. Waleński, Opolska Kronika Kulturalna (kwiecień-październik 1973 roku), „Wczoraj, Dzisiaj, Jutro", R. VII (1973), nr 3-4/24-25, s. 108; WBP Opole, Protokoły z posiedzeń Prezydium Zarząu i Zarządu OTKO 1976-1977-1978, sygn. 74, Informacja - Sprawozdanie Komisji ds. Współpracy z Polonia Zagraniczną przy Opolskim Towarzystwie Kulturalno-Oświatowym, s. 2; Kronika społeczno-kulturalna oprac. T. Soroczyński, „Kalendarz Opolski” 1978, Opole 1978, s. 226; K. Musioł, Towarzystwo Przyjaciół Opola. Kronika ruchu regionalnego, „Wczoraj, Dzisiaj, Jutro”, R. XI (1978), nr 2/43, s. 89; Kronika kulturalno-oświatowa wrzesień 1977-sierpień 1978, oprac. T. Soroczyński, „Kalendarz Opolski” 1979, Opole 1979, s. 271; T. Soroczyński, Opolskie Towarzystwo Kulturalno-Oświatowe. Kronika ruchu regionalnego, „Wczoraj, Dzisiaj, Jutro", R. XII (1979), nr 2-3/47-48, s. 136; WBP Opole, Protokoły z posiedzeń Prezydium Zarządu OTKO i Zarządu OTKO 1979 r., sygn. 95, Kontakty Opolskiego Towarzystwa Kulturalno-Oświatowego z Polakami z Polskiego Związku Kulturalno-Oświatowego w Czechosłowacji (1978), s. 2; T. Soroczyński, Opolskie Towarzystwo Kulturalno-Oświatowe. Kronika ruchu regionalnego, „Wczoraj, Dzisiaj, Jutro”, R. XII (1979), nr 2-3/47-48, s. 139; idem, Kronika społeczno-kulturalna wrzesień 1979-sierpień 1980, Kalendarz Opolski" 1981, Opole 1981, s. 228; WBP Opole, Protokoły z posiedzeń Prezydium Zarządu OTKO i Zarządu OTKO 1979 r., sygn. 95, Kontakty Opolskiego Towarzystwa Kulturalno-Oświatowego z Polakami z Polskiego Związku Kulturalno-Oświatowego w Czechosłowacji (1978), s. 3; Kronika kulturalno-oświatowa wrzesień 1977-sierpień 1978, oprac. T. Soroczyński, „Kalendarz Opolski” 1979, Opole 1979, s. 273.

235 T. Soroczyński, Opolskie Towarzystwo Kulturalno-Oświatowe. Kronika ruchu regionalnego, „Wczoraj, Dzisiaj, Jutro", R. XV (1981), nr 2/55, s. 70.

236 H. Kowalczyk, XI Festiwal Piosenki Polskiej, „Wczoraj, Dzisiaj, Jutro”, R. VIII (1974), nr 2/27, s. 55-59.

237 Ibidem, s. 59. 
Na Śląsku Opolskim także odbywało się wiele festiwali, np. Opolskie Święto Pieśni Ludowej w Gogolinie, w ramach którego wystąpił m.in. zespół „Gorole” zza Olzy ${ }^{238}$. Zespoły folklorystyczne oraz soliści chętnie brali udział w tych imprezach. W różnych miastach Opolszczyzny wystąpiły: chóry - „Lira” z Darkowa-Karwiny ${ }^{239}$, „Harfa” z Czeskiego Cieszyna, „Godula” z Gnojnika, zespoły - Pieśni i Tańca „Olza”240, „Górnik”, „Sibica”, „Melodia”, zespół dziecięcy „Rytmika” oraz Teatrzyk Lalek „Bajka” z Czeskiego Cieszyna. Natomiast w Czechosłowacji w Hawierzowie koncertował Harcerski Zespół Artystyczny „Legenda”241.

Na Opolszczyźnie organizowane były również recitale, m.in. z udziałem wybitnej solistki PZKO Jadwigi Niemcowej (sopran) i pianistki Wandy Miechowej. Wiosenne recitale miały miejsce w Krapkowicach, Głogówku, Kędzierzynie-Koźlu, Prudniku i Mosznej ${ }^{242}$.

\section{Teatr}

W ramach współpracy kulturalnej kontakty utrzymywali również aktorzy Teatru im. Jana Kochanowskiego w Opolu z aktorami Sceny Polskiej Teatru Cieszyńskiego. Aktorzy tej Sceny byli zapraszani na Opolskie Konfrontacje Teatralne ${ }^{243}$, występowali również poza konkursem w „Konfrontacjach”244, m.in. w 1984 r. Scena Polska wystawiła w Opolu Ptaka Jerzego Szaniawskiego ${ }^{245}$.

238 W placówkach kultury, „Opole”, R. XX (1989), nr 7 (227), s. 20.

239 T. Soroczyński, Opolskie Towarzystwo Kulturalno-Oświatowe. Kronika ruchu regionalnego (lipiecwrzesień 1984), „Wczoraj, Dzisiaj, Jutro”, R. XVIII (1984), nr 4/69, s. 76.

240 (jak), Opolskie Dni PZKO, „Wczoraj, Dzisiaj, Jutro”, R. XXI (1987), nr 4/81, s. 31; por. (s), Głuchołaskie Towarzystwo Społeczno-Kulturalne. Kronika ruchu regionalnego kwiecień-wrzesień 1980, „Wczoraj, Dzisiaj, Jutro", R. XIV (1980), nr 4/53, s. 94; J. Kośla, Towarzystwo Miłośników Grodkowa. Kronika ruchu regionalnego kwiecień-wrzesień 1980, „Wczoraj, Dzisiaj, Jutro”, R. XIV (1980), nr 4/53, s. 94.

241 Opolskie Towarzystwo Kulturalno-Oświatowe, „Wczoraj, Dzisiaj, Jutro”, R. XIX (1985), nr 1-2 /70-71 s. 73-74; por. Kronika społeczno-kulturalna wrzesień 1984 - sierpień 1985, oprac. T. Soroczyński, „Kalendarz Opolski" 1986, Opole 1986, s. 217; T. Soroczyński, Opolskie Towarzystwo Kulturalno-Oświatowe (październik - grudzień 1984). Kronika ruchu regionalnego, „Wczoraj, Dzisiaj, Jutro”, R. XIX (1985), nr 1-2/7071, s. 124; Kronika społeczno-kulturalna wrzesień 1984 - sierpień 1985, oprac. T. Soroczyński, „Kalendarz Opolski" 1986, Opole 1986, s. 213.

242 WBP Opole, Protokoły z posiedzeń Prezydium Zarządu OTKO i Zarządu OTKO 1979 r., sygn. 95, Kontakty Opolskiego Towarzystwa Kulturalno-Oświatowego z Polakami z Polskiego Związku Kulturalno-Oświatowego w Czechosłowacji (1978), s. 3; zob. Kronika kulturalno-oświatowa wrzesień 1977-sierpień 1978, oprac. T. Soroczyński, „Kalendarz Opolski” 1979, Opole 1979, s. 273.

243 Zob. WBP Opole, Protokoły z posiedzeń Prezydium Zarządu OTKO i Zarządu OTKO 1979 r., sygn. 95 Kontakty Opolskiego Towarzystwa Kulturalno-Oświatowego z Polakami z Polskiego Zwiazzku Kulturalno-Oświatowego w Czechosłowacji (1978), s. 3-4; WBP Opole, Protokoły z posiedzeń Prezydium Zarządu OTKO i Zarządu OTKO 1980 r., sygn. 96, Sprawozdanie z działalności Opolskiego Towarzystwa Kulturalno-Oświatowego w Opolu za rok 1979, s. 9.

T. Soroczyński, Opolskie Towarzystwo Kulturalno-Oświatowe. Kronika ruchu regionalnego, „Wczoraj, Dzisiaj, Jutro", R. XV (1981), nr 4/57, s. 78.

244 Zob. Opolskie Towarzystwo Kulturalno-Oświatowe, „Wczoraj, Dzisiaj, Jutro”, R. XIX (1985), nr 1-2 /7071, s. 73-74; Kronika społeczno-kulturalna wrzesień 1984-sierpień 1985, oprac. T. Soroczyński, „Kalendarz Opolski" 1986, Opole 1986, s. 217. 
W czasie pobytu w Opolu delegacji Zarządu Głównego PZKO z Czeskiego Cieszyna w Wydziale Kultury i Sztuki Urzędu Wojewódzkiego oraz OTKO odbyły się rozmowy w celu skonkretyzowania planów współpracy między Sceną Polską Teatru Cieszyńskiego i Teatrem im. Jana Kochanowskiego oraz między Teatrem Lalek „Bajka” z Czeskiego Cieszyna i Opolskim Teatrem Lalki i Aktora ${ }^{246}$. Podczas inauguracji roku kulturalno-artystycznego w 1983 r. w Teatrze im. Jana Kochanowskiego w Opolu wystąpił Zespół Pieśni i Tańca "Olza” działający przy PZKO w Czechosłowacji ${ }^{247}$.

Z okazji 35-lecia swojej działalności Scena Polska w Czeskim Cieszynie wystąpiła z premierą Dwóch teatrów Jerzego Szaniawskiego. W uroczystym wieczorze udział wziął Wojciech Zeidler, dyrektor Teatru im. Jana Kochanowskiego w Opolu ${ }^{248}$.

Na Opolszczyźnie przebywał również amatorski teatr działający przy Kole Miejscowym PZKO w Wędryni, który zaprezentował mieszkańcom Błotnicy Strzeleckiej, Leśnicy i Strzelec Opolskich przedstawienie K. Bergera Zbójnik ślqski - Ondraszek. Goście zwiedzili ponadto Górę św. Anny, złożyli tam kwiaty pod pomnikiem Czynu Powstańczego, a w Teatrze im. Jana Kochanowskiego spotkali się z kierownictwem tej placówki i z działaczami OTKO ${ }^{249}$.

Prezentowany artykuł obejmuje materiał, którego zakres chronologiczny kończy się na 1990 r., ale współpraca opolskiego i zaolziańskiego środowiska trwała nadal. Współpraca ta po 1990 r. przynosi jeszcze więcej kontaktów kulturalnych-oświatowych, zwłaszcza literackich. Literaci coraz częściej przyjeżdżali na spotkania do ZLP, stawali się jego członkami, uczestniczyli w Najeździe Poetów na Zamek Piastów Śląskich w Brzegu, plastycy mieli swoje wystawy w BWA, natomiast zespoły odwiedzały poszczególne miejscowości Opolszczyzny. Coraz więcej było również publikacji, zwłaszcza tomików wierszy wydawanych przez Oficynę Literacką „Wers”, poetów, których od dawna łączyły bliskie i serdeczne kontakty ze Śląskiem Opolskim, jak Wilhelm Przeczek czy Jan Pyszko. Opolscy literaci brali udział w „Kawiarence pod Pegazem", gdzie mieli swoje wieczory literackie.

Po 1990 r. kontakty społeczeństwa i władz Opolszczyzny z Polakami na Zaolziu nadal się rozwijały, pisał o tym m.in. Leszek Kara: „Biorąc pod uwagę kontakty środowiska pezetkaowskiego z towarzystwami regionalnymi w Polsce można stwierdzić, iż stosunki najbardziej serdeczne, najbardziej zażyłe i bliskie, nacechowane największym zrozumieniem dla naszej działalności, utrzymywane są z Opolszczyzną"250. Wymaga to jednak dodatkowej kwerendy, zwłaszcza po powstaniu w 1990 r. Kongresu Polaków w Republice Czeskiej, który jest kolejną instytucją, reprezentującą Polaków na Zaolziu.

\footnotetext{
246 Idem, Opolskie Towarzystwo Kulturalno-Oświatowe. Kronika ruchu regionalnego, „Wczoraj, Dzisiaj, Jutro", R. XV (1981), nr 4/57, s. 78.

247 Kronika społeczno-kulturalna województwa opolskiego wrzesień 1983-sierpień 1984, oprac. T. Soroczyński, „Kalendarz Opolski” 1985, Opole 1985, s. 260.

248 T. Soroczyński, Opolskie Towarzystwo Kulturalno-Oświatowe. Kronika ruchu regionalnego październik-grudzień 1986 r., „Wczoraj, Dzisiaj, Jutro”, R. XXI (1987), nr 1/87, s. 63.

249 Zob. T. Soroczyński, Opolskie Towarzystwo Kulturalno-Oświatowe. Kronika ruchu regionalnego kwiecień-wrzesień 1987 r., „Wczoraj, Dzisiaj, Jutro”, R. XXI (1987), nr 4/81, s. 84; Kronika społeczno-kulturalna Ślq̨ska Opolskiego (wrzesień 1987-sierpień 1988), oprac. T. Soroczyński, „Kalendarz Opolski” 1989, Opole 1989, s. 236. 


\section{Bibliografia \\ Monografie, opracowania}

Działalność Towarzystwa Rozwoju Ziem Zachodnich w latach 1957-1970, oprac. red. F. Hawranek, Warszawa-Wrocław 1973

Friedl J., Češi a Poláci na Těšínsku, Praha-Brno 2012

Gawrecki D. [et al.], Dějiny Českého Slezska 1740-2000, t. 1, t. 2, Opava 2003, s. 298-303

Haller M., Ruch oporu na Śląsku Cieszyńskim, Opole 1982

Jasiński Z., Działalność kulturalno-oświatowa Polaków za Olzq 1920-1938, Opole 1990

Jasiński Z., Mały leksykon nadolziański, Opole 1990

Kadłubiec D., Z biegiem Olzy", Opole 1986

Kamiński M.K., Kształtowanie się stosunków polsko-czechosłowackich w latach 1948-1960, Warszawa 2012

Kamiński M.K., Polsko-czechosłowackie stosunki polityczne 1945-1948, Warszawa 1990

Kunda B.S., Polska mniejszość narodowa w Czechosłowacji w latach 1945-1950, [w:] Z polsko-czechosłowackiego sqsiedztwa. Studia i szkice, red. E. Kopeć, Katowice 1985, s. 75-95

Leksykon jako koncepcja badań nad zbiorowościq polonijnq $w$ Czechosłowacji, red. Z. Jasiński, Opole 1986

Leksykon PZKO, red. M. Radłowska-Obrusník, O. Toboła, Czeski Cieszyn 1997

Nástin dějin Těšínska, oprac. M. Borák, D. Gawrecki, Ostrava 1992

Nowak K., Mniejszość Polska w Czechosłowacji 1945-1989. Między nacjonalizmem a ideq nacjonalizmu, Cieszyn-Katowice 2010

Pańko G., Polska i Polacy w Czeskiej opinii publicznej w okresie międzywojennym, „Acta Universitatis Wratislaviensis", nr 1829 (1996), s. 13-27

Pyszko J., Kawiarenka pod Pegazem 1989-2002, Jabłonków 2003

PZKO w roku 2007. Aneks do Leksykonu, red. F. Bałon, Czeski Cieszyn 2007

PZKO, red. P. Przeczek [et al.], Ostrava 1987

TRZZ na Opolszczyźnie 1957-1970, oprac. R. Hładko, Opole 1970

Wacławik A., Nasze zespoły folklorystyczne, [w:] Cudze chwalicie - swego nie znacie, red. J. Ondrusz, Czeski Cieszyn 1970, s. 29-31

Wanatowicz M.W., Historia społeczno-polityczna Górnego Ślq̨skq i Ślq̨ska Cieszyńskiego w latach 1918-1945, Katowice 1994

Zahradnik S., Czasopiśmiennictwo w języku polskim na terenach czechosłowackich, Opole 1989

Zahradnik S., Zaolziańskie ofiary okupacji hitlerowskiej (w byłych powiatach czeskocieszyńskim i frysztackim) 1939-1945, Opole 1988

Zahradnik S., M. Ryczkowski, Korzenie Zaolzia, Warszawa-Praga-Trzyniec 1992

Zderzenia i przenikanie kultur na pograniczach. Materiały z konferencji naukowej w Opolu, 1920.10.1987, red. Z. Jasiński, J. Korbel, Opole 1989

Ziemie odzyskane. Ziemie zachodnie. Zadania programowe Towarzystwa Rozwoju Ziem Zachodnich, oprac. zespół pod kier. W. Lechowicza, Poznań-Warszawa 1958 


\section{Artykuły w czasopismach}

(FA), Co dzień Polak narodowi służy! List zza Olzy, „Wczoraj, Dzisiaj, Jutro”, R. XX (1986), nr 4 (77), s. $73-74$

(jak), Opolskie Dni PZKO, „Wczoraj, Dzisiaj, Jutro”, R. XXI (1987), nr 4 (81), s. 29-31

(m. j.), 25 lat „Bajki”, „Opole”, R. IV (1973), nr 11 (43), s. 33

Adamiec F., Byliśmy na XIV Zjeździe Polskiego Zwiqzku Kulturalno-Oświatowego w Czeskim Cieszynie, „Kalendarz Opolski” (1984), s. 230-234

Berger W.A., Opole...Opole, „Zwrot”, R. XXXVIII (1986), nr 8 (441), s. 20-21

Gadziński A., Owocny trud społecznej aktywności, „Wczoraj, Dzisiaj, Jutro”, R. IX (1975), nr 2 (31), s. 5-13

Goczoł J., Znad Olzy, „Opole”, R. XVIII (1987), nr 6 (202), s. 3

Hajduk J., Nowa antologia tekstów górniczych, „Opole”, R. VI (1975), nr 4 (60), s. 28-29

Hajduk-Nijakowska J., Sowo polskie z Zaolzia, „Kalendarz Opolski” (1988) s. 191-192

-hak-, Inny smak XV FPP, „Zwrot”, R. XXXI (1979), nr 5 (354), s. 62-63

Hoszowski E., Grodków-Skrzeczoń - pożyteczna współpraca, „Wczoraj, Dzisiaj, Jutro”, R. XI (1977), nr 4 (41), s. $45-46$

j.st., Dwaj poeci z Zaolzia, „Kalendarz Opolski” (1981), s. 163-164

Jasiński Z., Aktywni wszędzie potrzebni, „Wczoraj, Dzisiaj, Jutro”, R. XI (1977), nr 3 (40), s. 38-41

Jasiński Z., Kurs dla nauczycieli polskich z Czechosłowacji, „Wczoraj, Dzisiaj, Jutro”, R. XVIII (1984), nr 3/68, s. 28-32

Jasiński Z., Olescy miłośnicy żegnajq się z Opolszczyznq, „Wczoraj, Dzisiaj, Jutro”, R. IX (1975), nr 3 (32), s. 36-41

Kara L., Badacze i animatorzy kultury ziemi cieszyńskiej. List z Zaolzia, „Wczoraj, Dzisiaj, Jutro”, R. XIX (1985), nr 4 (73), s. 58-64

Kara L., Ćwierćwiecze Grupy Literackiej '63. Listy zza Olzy, „Wczoraj, Dzisiaj, Jutro”, R. XXII (1988), nr 3-4 (84-85), s. 117-120

Kara L., Festiwal PZKO w Trzyńcu. List zza Olzy, „Wczoraj, Dzisiaj, Jutro”, R. XIX (1985), nr 3 (72), s. $62-64$

Kara L., Jubileusz Józefa Firli, Wczoraj, Dzisiaj, Jutro", R. XXII (1988), nr 3-4 (84-85), s. 121-125

Kara L., Jubileusz PZKO. Listy zza Olzy, „Wczoraj, Dzisiaj, Jutro”, R. XXII (1988), nr 1-2 (82-83), s. 136144

Kara L., Jubileusze chórów i Andrzeja Kubisza. List zza Olzy, „Wczoraj, Dzisiaj, Jutro”, R. XX (1986), nr 1-2 (86), s. 143-148

Kara L., Jubileuszowy FPP w Karwinie, „Wczoraj, Dzisiaj, Jutro”, R. XXIII (1989), nr 2-3 (87-88), s. 102103

Kara L., Kuźnia młodych społeczników, „Wczoraj, Dzisiaj, Jutro”, R. XX (1986), nr 3 (86), s. 77-82

Kara L., Odszedł Emanuel Guziur. List zza Olzy, „Wczoraj, Dzisiaj, Jutro”, R. XXIII (1989), nr 1 (86), s. $78-79$

Kara L., Pod znakiem jubileuszy. List zza Olzy,„,Wczoraj, Dzisiaj, Jutro”, R. XXIII (1989), nr 4 (89), s. 38-48

Kara L., Pomnik Jana Kubisza w Cieszynie. List zza Olzy, „Wczoraj, Dzisiaj, Jutro”, R. XXIII (1989), nr 1 (86), s. 77-78

Kara L., Święto teatru. Listy zza Olzy, „Wczoraj, Dzisiaj, Jutro”, R. XXI (1987), nr 2-3 (87), s. 130-138 
Kara L., Uhonorowanie Sceny Polskiej TC. List zza Olzy, „Wczoraj, Dzisiaj, Jutro”, R. XXIII (1989), nr 1 (86), s. 80

Kara L., Z wizytq w Opolu, „Zwrot”, R. XXXII (1980), nr 10 (371), s. 14-16

Karp M., Z troskq o dobra najwyższe i ... najbliższe, „Wczoraj, Dzisiaj, Jutro”, R. XVII (1983), nr 2-3 (83), s. 29-35

Kaszper K., Dwa oblicza regionu, „Opole”, R. XVII (1986), nr 3 (187), s. 23-24

Kaszper K., Głód uczestnictwa, „Opole”, R. XVII (1986), nr 6 (190), s. 26

Kaszper K., Granica zmienia optykę, „Opole”, R. XVII (1986), nr 4 (188), s. 24-25

Kaszper K., Mosty, festiwale, „Opole”, R. XVII (1986), nr 10 (194), s. 26

Kaszper K., Regionalizm raz jeszcze, „Opole”, R. XVII (1986), nr 1 (185), s. 25-26

Kasztura G., Działania Armii Czerwonej na Ślqssku Cieszyńskim wiosnq 1945 roku a kwestia powojennej przynależności państwowej Zaolzia, „Pamiętnik Cieszyński”, t. 21 (2016), s. 107-125

Kętrzyński Z., Samosiewy nad Olzq, „Wczoraj, Dzisiaj, Jutro”, R. XXIII (1989), nr 1 (86), s. 59-60

Kowalczyk H., Festiwal bez przebojów?, „Zwrot”, R. XXVIII (1976), nr 7 (320), s. 11-12

Kowalczyk H., Wsi spokojna, wsi wesoła..., „Kalendarz Opolski” (1975), s. 262-265

Kowalczyk H., XI Festiwal Piosenki Polskiej, „Wczoraj, Dzisiaj, Jutro”, R. VIII (1974), nr 2 (27), s. 55-59

Kozołub L., Krzewiciel kultury polskiej w Czeskim Cieszynie. Listy zza Olzy, „Wczoraj, Dzisiaj, Jutro”, R. XXIII (1989), nr 2-3 (87-88), s. 98-101

Kunda B.S., Pisarz z Ostrawy, „Opole”, R. III (1972), nr 2 (22), s. 15.

Musioł K., Towarzystwo Przyjaciół Opola. Kronika ruchu regionalnego, „Wczoraj, Dzisiaj, Jutro”, R. XI (1978), nr 2 (43), s. 89

Nasz pierwszy Zjazd, „Wczoraj, Dzisiaj, Jutro”, R. VI (1972), nr 2 (19), s. 3-4

Nowak K., Nieznany plan przejęcia władzy na Zaolziu przez Polaków w 1944 roku, „Pamiętnik Cieszyński", t. 4 (1994), s. 148-151

Nowicka D. Przedstawiamy Franciszka Bałona współautora wystawy „Grafika-fotografika”, „Opole”, R. VIII (1977), nr 10 (90), s. 31

Opolskie Towarzystwo Kulturalno-Oświatowe w 1984 roku, „Wczoraj, Dzisiaj, Jutro”, R. XIX (1985), nr 1-2 (70-71), s. 69-75

Orłowska J., Na trasie E-7, „Kalendarz Opolski” (1986), s. 137-142

Pacułt R., Towarzystwo Ziemi Kozielskiej w latach 1972-1975, „Wczoraj, Dzisiaj, Jutro”, R. X (1976), nr 1 (34), s. 25-31

Pacułt R., Współpraca Towarzystwa Ziemi Kozielskiej z kołem Polskiego Zwiqzku Kulturalno-Oświatowego w Czeskim Cieszynie, „Wczoraj, Dzisiaj, Jutro”, R. VIII (1974), nr 1 (26), s. 55-58

Pałys P., Administracja polska wobec ludności czeskiej na pograniczu polsko-czechosłowackim w latach 1945-1947, „Śląski Kwartalnik Historyczny Sobótka”, R. LV (2000), nr 2, s. 211-241

Pałys P., Jak kształtowała się granica, „Fabryka Silesia - Kwartalnik”, nr 1 (6/2014), s. 13-17

Pałys P., Konflikt polsko-czechosłowacki z lat 1945-1946 w aktach Komitetów Powiatowych PPR w Raciborzu i Głubczycach, „Śląsk Opolski”, nr 3 (1991), s. 19-21

Pałys P., Polsko-czechosłowacki spór o przynależność ziemi kłodzkiej w latach 1945-1947, „Kwartalnik Opolski”, R. XLI (1995), nr 3-4, s. 31-49

Pałys P., Repatrianci z Czechosłowacji w aktach Powiatowych Oddziałów Państwowego Urzędu Repatriacyjnego na Ślqsku Opolskim, „Śląski Kwartalnik Historyczny Sobótka”, R. XLIX (1994), nr 1-2, s. $129-136$ 
Pałys P., Sytuacja na Zaolziu u schyłku 1945 roku w ocenie Powiatowego Urzędu Informacji i Propagandy w Raciborzu, „Pamiętnik Cieszyński”, t. 4 (1994), s. 152-154

Pałys P., Uchodźcy z Zaolzia na Opolszczyźnie w latach 1945-1948, „Pamiętnik Cieszyński”, t. 4 (1992), s. $110-114$

Pałys P., W kwestii czeskiej akcji zbrojnej w Kłodzkiem, Głubczyckiem i Raciborskiem oraz polskiej na Ślq̨sku Cieszyńskim w 1945 r., „Pamiętnik Cieszyński”, t. 13 (1998), s. 44-49

Pałys P., Ze źródeł do polsko-czechosłowackiego konfliktu granicznego w latach 1945-1947, „Pamiętnik Cieszyński", t. 11 (1996), s. 73-78

Perspektywa Południe, „Opole”, R. I (1970), nr 5, s. 23

Pochroń E., Kultura ludowa - żywa, „Zwrot”, R. XXXI (1979), nr 1 (350), s. 31-32

Pochroń E., List z Opola, „Zwrot”, R. XXVII (1975), nr 2 (303), s. 38-39

Pochron E., O rekonstrukcji Opola, teatrze i dziennikarzach, „Zwrot”, R. XXX (1978), nr 8 (345), s. 12-13

Pochroń E., Opolanie lubiq klasykę, „Zwrot”, R. XXXI (1979), nr 7 (356), s. 54-55

Polacy spoza Polski, „Opole”, R. XIV (1983), nr 12 (160), s. 26

Przeczek W., Bogusław Żurakowski, „Zwrot”, R. XXXI (1979), nr 1 (350), s. 46-48

Przeczek W., Polonica w poezji Jana Pilařa, „Opole”, R. XIX (1988), nr 5 (213), s. 8-10, 18

Pszczyński K., Dwa dni z „Olzq”, „Wczoraj, Dzisiaj, Jutro”, R. XVII (1983), nr 4 (65), s. 39-42

Pszczyński K., Wystawa Bronisława Firli w Opolu, „Zwrot”, R. XXIX (1977), nr 6 (331), s. 51

Pszczyński K.P., Ekslibrysy w Opolu, „Zwrot”, R. XXXI (1979), nr 2 (351), s. 75

Pszczyński K.P., Plastyka z Czeskiego Cieszyna na Opolszczyźnie, „Zwrot”, R. XXXII (1980), nr 12 (373), s. 61

Santarius K., Polski Zwiqzek Kulturalno-Oświatowy w Czechosłowacji, „Wczoraj, Dzisiaj, Jutro”, R. VI (1972), nr 2 (19), s. 91-97

Sikora W., Festiwal PZKO 1974, „Kalendarz Opolski” (1975), s. 259-262

Stebel J., Żwirowisko, „Kalendarz Opolski” (1972), s. 345-348

Szmeja H., 30 lat pracy nad utrwalaniem przyjaźni czechosłowacko-polskiej, „Kalendarz Opolski” (1979), s. 225-229

Sztabla E., Szkolnictwo polskie w Czechosłowacji, „Wczoraj, Dzisiaj, Jutro”, R. VIII (1974), nr 4 (29), s. 1417

Świerc P., Zaolziańskie chóry na Opolszczyźnie, „Wczoraj, Dzisiaj, Jutro”, R. XIX (1985), nr 1-2 (70-71), s. $92-94$

Wacławik A., Nasze zespoły regionalne, „Kalendarz Opolski” (1973), s. 342-344

Waleński B., W Jabłonkowie chcq, „Wczoraj, Dzisiaj, Jutro”, R. XVIII (1984), nr 3 (68), s. 33-35

Zahradnik S., Leksykon Polaków w Czechosłowacji, Opole 1990, „Zwrot”, R. XLII (1990), nr 2 (482), s. $62-63$

Zahradnik S., Macierz Szkolna w Czechosłowacji, „Kalendarz Opolski” (1986), s. 130-136

Zarzeczny B., Życie literacko-artystyczne na Zaolziu, „Wczoraj, Dzisiaj, Jutro”, R. XVIII (1984), nr 4 (69), s. 31-39

Żurakowski B., Młodzi poeci cieszyńscy, „Opole”, R. VIII (1977), nr 5 (85), s. 26-28 


\section{Relacje władz i społeczeństwa Ślqska Opolskiego $z$ Polakami na Zaolziu (wybrane elementy)}

Streszczenie: Artykuł przedstawia wybrane formy kontaktów społeczeństwa i władz Opolszczyzny z Polakami żyjącymi na Zaolziu. Koncentrują się one przede wszystkim na sferze kulturalno-oświatowej. Autorka w niniejszym opracowaniu przedstawiła współpracę nawiązaną przez organizacje na Śląsku Opolskim, takie jak Opolskie Towarzystwo Kulturalno-Oświatowe, Towarzystwo Przyjaciół Opola czy regionalne towarzystwa z poszczególnych miejscowości Opolszczyzny z polskimi instytucjami działającymi na Zaolziu, związanymi z Polskim Związkiem Kulturalno-Oświatowym. Informacje zaczerpnięto z dokumentów Archiwum Państwowego w Opolu, Archiwum Związkowego Polskiego Związku Kulturalno-Oświatowego, Opolskiego Towarzystwa Kulturalno-Oświatowego, periodyków oraz kronik towarzystw regionalnych. Opisują one wspólne inicjatywy i kontakty kulturalne, m.in. wyjazdy delegacji, wymianę zespołów artystycznych oraz wymianę wydawnictw.

\section{Relations between the authorities and community of Opolian Silesia and Poles in Zaolzie (selected elements)}

Abstract: The article presents selected forms of interaction between society and the Opole authorities with Poles living in Zaolzie. These interactions are concentrated in the cultural-educational sphere. The author of this study describes joint activities undertaken by organisations in Opolian Silesia, such as the Opole Cultural-Educational Association, the Association of Friends of Opole and regional associations from individual towns in the Opole region, with Polish institutions working in Zaolzie which are connected with the Polish Cultural-Educational Society. Information is drawn from documents from the National Archives in Opole, the Archive of the Union of the Polish Cultural-Educational Society, the Opole Cultural-Educational Association, periodicals and chronicles of regional associations. These documents describe common initiatives and cultural contacts, among others business trips, exchanges of artistic groups and publishers.

Słowa kluczowe: Śląsk Opolski, Zaolzie, Opolskie Towarzystwo KulturalnoOświatowe, Polskie Towarzystwo Kulturalno-Oświatowe, towarzystwa regionalne

Key words: Opolian Silesia, Zaolzie, Opole Cultural-Educational Association, Polish Cultural-Educational Association, regional associations 